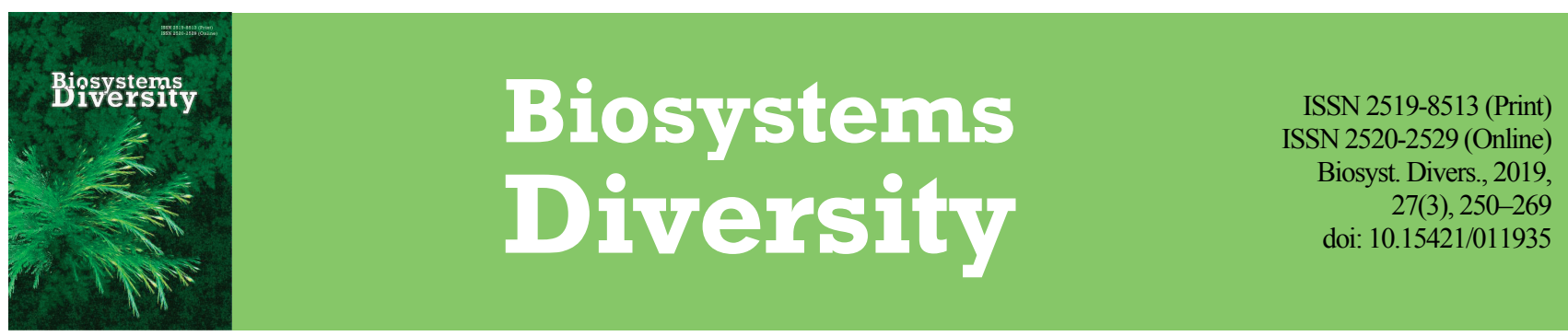

\title{
Morphological variability of Bembidion minimum (Coleoptera, Carabidae) populations under the influence of natural and anthropogenic factors
}

\author{
V. O. Komlyk, V. V. Brygadyrenko \\ Oles Honchar Dnipro National University, Dnipro, Ukraine
}

Article info

Received 12.06.2019

Received in revised form 09.07.2019

Accepted 10.07.2019

Oles Honchar Dnipro National University, Gagarin av., 72,

Dnipro, 49010, Ukraine.

Tel.: +38-066-21-21-708

E-mail:slinko@ua.fm,

brigad@ua.fm

\begin{abstract}
Komlyk, V. O., \& Brygadyrenko, V. V. (2019). Morphological variability of Bembidion minimum (Coleoptera, Carabidae) populations under the influence of natural and anthropogenic factors. Biosystems Diversity, 27(3), 250-269. doi:10.15421/011935
\end{abstract}

Morphological variability is the result of interaction between genetic diversity of the population and environmental selection. Despite the large number of studies of morphological variability of ground beetles, there is very little research dedicated to influence of environmental factors on it. This article discusses the influence of natural and anthropogenic factors on the variability of Bembidion minimum (Fabricius, 1792). B. minimum is a West Palearctic species which is distributed in North Africa, Europe, Western Asia. It is a macropterous species that lives in humid biotopes along the shores of seas, rivers and standing water bodies. 410 specimens were collected from 12 ecosystems differing by plant cover, degree of litter development, mechanical composition of the soil, mineralization and acidity of soil solution, type and intensity of anthropogenic impact. 13 linear characteristics, one angular characteristic, density of elytra puncturing and contrast of spots on the beetles' elytra were measured. Additionally 6 morphometric indices were calculated. More than a third of the variability of imagoes in the studied populations was found to be determined by the general body size. Sexual dimorphism was observed on all linear parameters and most morphometric indices. Females do not differ from males in the back angles of the prothorax. Natural and anthropogenic factors to a greater or lesser degree were shown to affect the morphological variability of $B$. minimum: soil acidity and mineralization have the greatest impact. The soil acidity causes significant variability of most linear parameters; mineralization - body length, head length, prothorax length and width, elytra width. Plant cover and mechanical composition of the soil have a slight impact on imago morphology. The type and structure of vegetation significantly affect head width, prothorax length and width, and the mechanical composition of the soil - body length and head length. Degree of litter development does not cause significant changes in the linear dimensions of beetles. With thickening of the litter the posterior spots on the elytra become brighter, they have sharper contours, and density of elytra puncturing also changes. The mean value of the back angles is affected by the herb layer of meadow vegetation, soil mineralization and acidity. The variability of morphometric indexes under the influence of natural factors was found to be lower than variability of linear characteristics. The recreational load and cattle grazing cause similar changes in linear measurements and morphometric indexes of B. minimum. With escalation of these factors, the body length, length and width of elytra of both females and males decrease. Assessing the natural morphological variability of populations in ecosystems whose environmental factors are within extreme and sub-extreme values for a given population is a promising direction of research in modern ecology.

Keywords: population variability; sexual dimorphism; morphometrics; riparian beetles.

\section{Introduction}

Insects react in various ways to changes in environmental conditions: changes in numbers, range, morphology etc. Invertebrate populations "accumulate" the influence of environmental factors over a certain time period, therefore they can serve as rather convenient bioindicators of environmental conditions (Moskalev et al., 2015). The results of the influence of a particular factor are determined by the duration and intensity of exposure, on the one hand, and the effectiveness of compensatory mechanisms at the molecular, genetic, cellular, organismic, population, and ecosystem levels, on the other hand (Brygadyrenko \& Slynko, 2015). Body size is one of the main characteristics of living organisms, which is associated with the life history of the individual (with the conditions in which its ontogenesis occurred), with its physiological patterns (individual features of gene expression) and environmental interactions within the ecosystem: trophic connections with food objects, predators and parasites (Brygadyrenko \& Reshetniak, 2016). The study of the relationship between the body size of insects and the type of habitat is important for understanding the basic regularities of their biotopic distribution and geographical extension (Dangalle et al., 2013). The individuals that make up the population are not identical: they vary in size, duration of ontogenesis, the intensity of anabolism and catabolism. Morphological variability is a property of populations, the total result of the adaptation of individuals to the sum of all effects of environmental factors (Sukhodolskaya \& Saveliev, 2014). The study of morphological variability under the influence of environmental factors contributes to the understanding of many ecological processes, makes it possible to assess the potential sustainability of a population, its ability to remain constant under changing conditions, and to identify the boundaries of potential and realized ecological niche (Sota et al., 2000; Barton et al., 2011; Brygadyrenko \& Korolev, 2015).

Ground beetles (Coleotera, Carabidae) are sensitive to the effects of abiotic and biotic factors, they quickly respond to environmental changes (Brygadyrenko, 2016a), and therefore they are often used as bioindicators (Grumo \& Lovei, 2016). Thiele (1977) suggested that the most pronounced morphological adaptations of carabids are associated with specialized dietary regimes. Erwin (1979), on the other hand, presented observations indicating that there are probably links between the morphology and ecology of carabids. Despite the large amount of data on the morphological variability of abundant species of ground beetles (Brygadyrenko \& Reshetniak, 2014), there is very little material on the influence of individual environmental factors on them. The intraspecific morphological variability of carabids is not well studied (Sukhodolskaya \& Saveliev, 2017). Usually, research on the influence of environmental factors on the morphometric variability of ground beetles is limited to measuring only the elytra length and is carried out by methods that do not allow one to single out a specific determining (limiting) environmental factor (Sukhodolskaya \& Saveliev, 2014). In particular, this applies to the study of ground 
beetles of riparian ecosystems. The shores of water bodies include a large number of microbiotopes that differ in microclimate and edaphic conditions. The littoral zones of water bodies and estuaries are characterized by the predominance of many species of ground beetles which are absent in other areas (Putchkov, 2012). Species of the genus Bembidion occupy most of these biotopes. We previously studied the morphological variability of three species of the genus Bembidion: B. varium (Olivier, 1795), B. articulatum (Panzer, 1796) and B. aspericolle (Germar, 1829) (Slinko et al., 2008; Brygadyrenko \& Slynko, 2015; Komlyk \& Brygadyrenko, 2019). This article is devoted to the study of the morphological variability of B. minimum (Fabricius, 1792), which is widely distributed in riparian biotopes.

One of the first references to B. minimum (Fabricius, 1792) was made by Band (1892), who described the size, morphological features, and the habitat of this species. B. minimum is a West Palearctic species which is distributed in North Africa, Europe, West Asia (Hurka, 1996). In Europe, the species lives in Bosnia, Herzegovina, Bulgaria, Romania (Hieke \& Wrase, 1988; Nitzu, 2003) and Lithuania (Tamutis et al., 2011). B. minimum is abundant in coastal areas in most of Great Britain: England, Scotland (West Lowlands), Ireland (Lindroth, 1974), its occurrence decreases in the north of the country (Luff, 1998). The only record of the species in Northern Ireland from Johnson \& Halbert (1902) indicates that the species was widespread in Ireland in the last century. Lindroth (1985) indicates that B. minimum is spread along the coasts of sea and fjords in all districts of Denmark; there are no or few records from the north-west and north-east coasts of Jutland or from the north and west coasts of Zealand. In the south of Sweden B. minimum is found exclusively on the sea coasts, generally distributed along the west coast; in Norway, it is a rare species, in Finland it is found along the coast (Lindroth, 1985). In Egypt, the species is very rare in settlements located along the coast of the Mediterranean Sea and the Sinai Peninsula, as these habitats are disturbed by urbanization and tourist settlements (Abdel-Dayem, 1998). In Russia, B. minimum is distributed in the northern, central and southern parts of the Russian Plain, in Siberia, Transbaikalia and the Altai-Sayan mountain country (Kryzhanovskij et al., 1995), there are a few records from the Southern Karelian Isthmus (Lindroth, 1985), it is quite common in the Republic of Adygea in coastal areas (Zamotajlov \& Nikitsky, 2010). In Ukraine, B. minimum is distributed in the Transcarpathian Lowland, in the Carpathians, RightBank and Left-Bank Polesie, the zone of broad-leaved forests, the RightBank and Left-Bank Forest-Steppes, and the northern subzone of RightBank and Left-Bank Steppes (Putchkov, 2011, 2012).

B. minimum lives in humid biotopes along the shores of seas, rivers, and standing water bodies (Lindroth, 1985). It prefers muddy, moderately humid and slightly shady places, among herbaceous plants (for example, plant associations of Juncus, Equisetum and others) and under bushes. It is a halophile which is usually found in high numbers (sometimes up to $20 \mathrm{ind} . / \mathrm{m}^{2}$ ) on salt marshes and marine clay soils, on the banks of saline and brackish water bodies (Desender \& Maelfait, 1999), less often on the banks of fresh water bodies (Zherebcov, 2000; Zamotajlov \& Nikitsky, 2010). B. minimum is one of the indicators of soil salinity (Schultz, 2000). B. minimum is widely distributed in polders (Meijer, 1974). The beetles often run about in sunny weather on exposed spots (Lindroth, 1985). B. minimum is a spring-summer species, breeding occurs in spring (Lindroth, 1985). It is macropterous, having functional flight muscles. $B$. minimum is characterized by high flight activity of both sexes during the entire existence of imago. In this species, both sexes and all ages of beetles participate in migratory activity (Matalin, 2003). It flies towards light, especially to polarized light (Szentkiralyi et al., 2005). B. minimum beetles swim well (Turin, 2000).

As a result of studies of the molecular variability of $B$. minimum from the shores of the Baltic Sea, it was deduced that the species has two haplotypes: one haplotype is limited to coastal habitats and the other occurs within the interior. This distribution is contrary to the wide distribution area and high mobility of this species (Kamer et al., 2008). The genetic structure and diversity of B. minimum has been studied on a regional and Western European scale for more than 1600 individuals from all remaining salt marshes in Belgium and from a number of European etalon areas. The average value of gene diversity is not related to the habitat or population size of B. minimum. From $2 \%$ to $6 \%$ of the total genetic diversity is explained by differentiation of populations. Genetic differentiation of $B$. minimum is significant at different geographic scales with higher values at a larger scale. Kamer et al. (2008) indicate that habitat fragmentation has not yet led to genetic changes, probably due to the large size of the $B$. minimum population, even in very small salt marshes. The observed genetic differentiation suggests that metapopulations on a relatively large geographical scale still function in this highly mobile species. Reconstruction of even small salt marshes can have a positive effect on the conservation for the long-term survival of these specialized ground beetles (Desender \& Verdyck, 2001). The karyotype of B. minimum was studied (Rozek \& Rudek, 1992).

B. minimum is associated with specific habitats (Eyre \& Luff, 2004). The zonal distribution of the species positively correlates with tides in excess of 20-40 cm (Irmler et al., 2002). According to the results of many studies, it is known that this species successfully increases its number in stressed habitats, for example, under the conditions of invasion of some plant species. Despite the negative impact of the invasion of Elymus athericus (Link) Kerguelen on the abundance of various halophilous ground beetle species, $B$. minimum increases its abundance in areas covered by this species of cereal. These areas are characterized by a lower percentage of halophilous species of ground beetles and their greater diversity. This species of ground beetle can be used in bioindication (Georges et al., 2011). B. minimum increases its abundance in the conditions of mowing and grazing sheep. Grazing and mowing make the areas open and therefore more preferable for some halophilous species, including B. minimum (Petillon et al., 2007).

Thus, B. minimum is a convenient object for a complex study of the influence of environmental factors on morphological variability. The purpose of this article is to examine the morphological variability of $B$. minimum under the influence of natural and anthropogenic factors (recreational load, cattle grazing) and determine the factors that most affect the variability of this species of ground beetle.

\section{Materials and methods}

The research was carried in 12 ecosystems in the Mahdalinovka, Novomoskovsk, Pavlograd and Sinelnikovo districts of Dnipropetrovsk region (Ukraine). The ecosystems differed (Fig. 1, Table 1) in composition of herb layer, thickness of the litter, mechanical composition of the soil, acidity and mineralization of the soil solution, degree of recreational load and the intensity of cattle grazing.

Methodology for determination the total mineralization and acidity of the soil is described earlier in our article (Brygadyrenko \& Slynko, 2015). For determination of the composition of the herb layer, a square of $4 \mathrm{~m}^{2}$ was selected and photographed on each sample plot, and a herbarium was collected. The density of the herb layer was determined from photographs by expert assessment. Thickness of litter was measured in each studied ecosystem using a ruler in 10 locations. Recreational load was determined by direct observation, and also by the number of human traces and amount of household waste detected (Muhar et al., 2002). The effect of cattle grazing was determined visually by the presence of animal trails and feces (Kikoti \& Mligo, 2015).

Specimens of $B$. minimum were collected using soil traps and manually using an aspirator. The beetles were frozen during 24 hours in a refrigerating chamber and then laid onto cotton mats, preliminarily straightened (to maintain proportions, we monitored the orientation of the head and prothorax). Each beetle was assigned a serial number including the ecosystem number and sex of the specimen (female, male). Photographs of the collected insects were taken using binocular MBS-10 and a digital camera of 5 megapixel resolution (Fig. 2). Morphometric measurements were performed using photographs in the TpsDig 2.17 program (F. James Rohlf, State University of New York at Stony Brook, USA, 2004). 13 linear characteristics, 1 angular characteristic, density of pores on the elytra, contrast of the light spots of the left and right elytra were measured (Brygadyrenko \& Fedorchenko, 2008; Brygadyrenko \& Korolev, 2015; Komlyk \& Brygadyrenko, 2019). Six morphometric indices were calculated (Brygadyrenko \& Reshetniak, 2014; Brygadyrenko \& Slynko, 2015; Komlyk \& Brygadyrenko, 2019). 

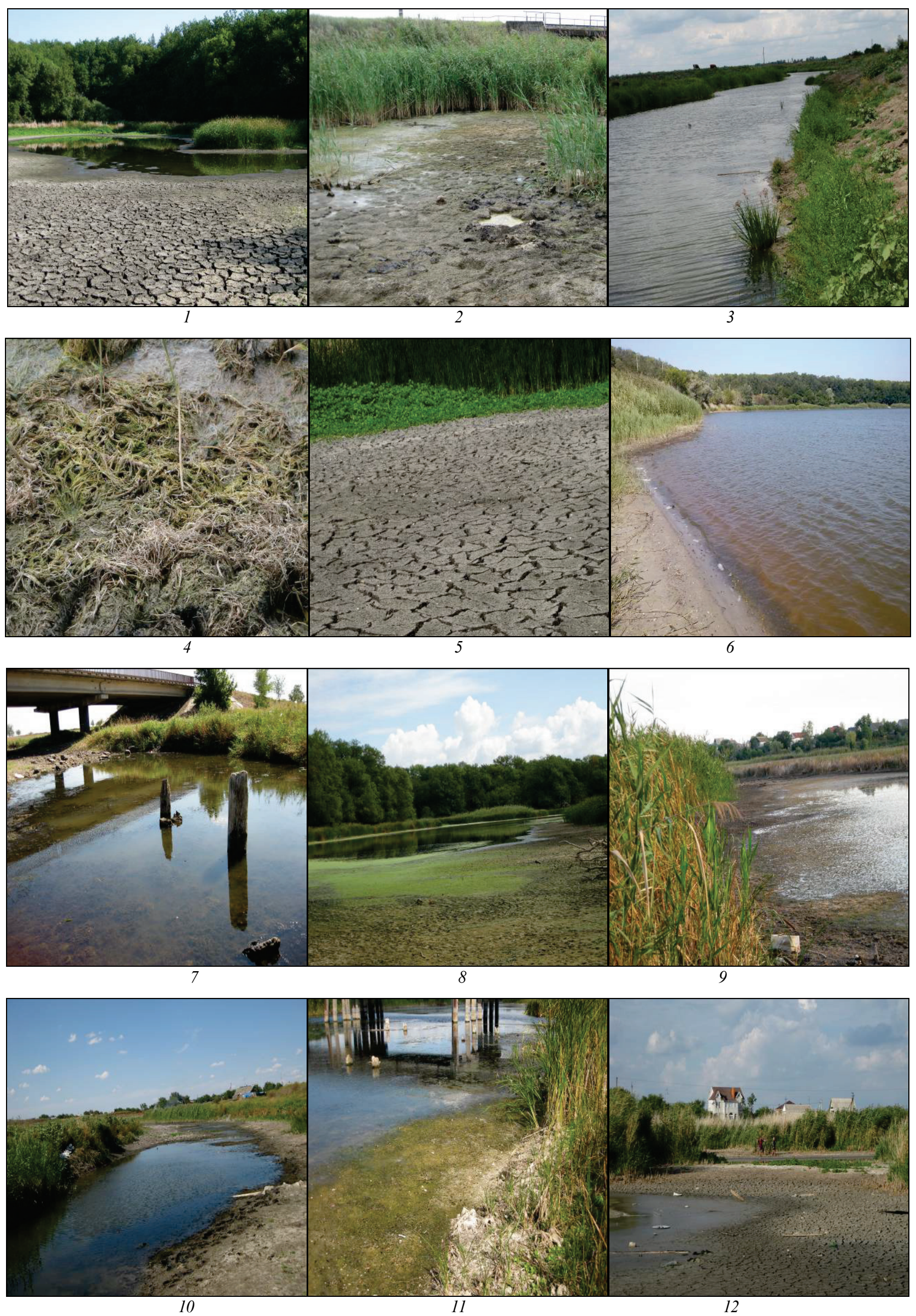

Fig. 1. Vegetation of the sample plots 
Table 1

Brief characteristic of ecosystems (Dnipropetrovsk region, Ukraine) where B. minimum was collected

\begin{tabular}{|c|c|c|c|c|c|c|c|c|c|c|}
\hline $\begin{array}{l}\text { Eco- } \\
\text { sys- } \\
\text { tem }\end{array}$ & $\begin{array}{l}\text { Administra- } \\
\text { tive district }\end{array}$ & $\begin{array}{l}\text { Ecosystem } \\
\text { coordinates }\end{array}$ & $\begin{array}{l}\text { Mechanical } \\
\text { composition il } \\
\text { of soil }\end{array}$ & $\begin{array}{l}\text { Salt content } \\
\text { in soil solution, } \\
\mathrm{g} / \mathrm{L} \\
\end{array}$ & $\begin{array}{l}\mathrm{pH} \text { of } \\
\text { soil } \\
\text { solution }\end{array}$ & $\begin{array}{l}\text { Density of herb layer (\%) } \\
\text { and dominating plant species }\end{array}$ & $\begin{array}{l}\text { Average litter } \\
\text { thickness, cm }\end{array}$ & $\begin{array}{c}\text { Degree of } \\
\text { recreational } \\
\text { load, points* }\end{array}$ & $\begin{array}{c}\text { Impact of } \\
\text { cattle grazing, } \\
\text { points** }\end{array}$ & $\begin{array}{l}\text { Number of studied } \\
\text { individuals (females } \\
\text { and males)*** }\end{array}$ \\
\hline 1 & $\begin{array}{c}\text { Novo- } \\
\text { moskovsk }\end{array}$ & $\begin{array}{l}48^{\circ} 40^{\prime} 04.3^{\prime \prime} \mathrm{N} \\
35^{\circ} 20^{\prime} 18.8^{\prime \prime} \mathrm{E}\end{array}$ & sandy loam & 0.35 & 8.38 & 0 & 0 & 0 & 0 & $39(20 f, 19 m)$ \\
\hline 2 & $\begin{array}{c}\text { Novo- } \\
\text { moskovsk }\end{array}$ & $\begin{array}{l}48^{\circ} 37^{\prime} 37.5^{\prime} \mathrm{N} \\
35^{\circ} 21^{\prime} 14.2^{\prime \prime} \mathrm{E}\end{array}$ & sandy loam & 0.37 & 8.17 & 0 & 0 & 3 & 3 & $40(28 f, 12 m)$ \\
\hline 3 & Pavlograd & $\begin{array}{l}48^{\circ} 30^{\prime} 33.0^{\prime} \mathrm{N} \\
36^{\circ} 04^{\prime} 44.0^{\prime} \mathrm{E}\end{array}$ & sand & 0.87 & 8.60 & $\begin{array}{l}\text { 90\%: Xanthium albinum (Widd.) } \\
\text { Scholz }(50 \%) \text {, Chenopodium } \\
\text { album L. }(30 \%) \text {, Bolboschoenus } \\
\text { maritimus (L.) Palla }(10 \%)\end{array}$ & 0 & 2 & 2 & $27(14 \mathrm{f}, 13 \mathrm{~m})$ \\
\hline 4 & Sinelnikovo & $\begin{array}{l}48^{\circ} 29^{\prime} 33.0^{\prime \prime} \mathrm{N} \\
35^{\circ} 21^{\prime} 49.0^{\prime \prime} \mathrm{E}\end{array}$ & loam & 1.12 & 8.22 & 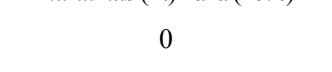 & 4 & 3 & 3 & $38(22 f, 16 m)$ \\
\hline 5 & $\begin{array}{c}\text { Novo- } \\
\text { moskovsk }\end{array}$ & $\begin{array}{l}48^{\circ} 40^{\prime} 03.11^{\prime \prime} \mathrm{N} \\
35^{\circ} 20^{\prime} 17.3^{\prime \prime} \mathrm{E}\end{array}$ & loam & 1.43 & 7.64 & 0 & 0 & 0 & 0 & $40(16 \mathrm{f}, 14 \mathrm{~m})$ \\
\hline 6 & $\begin{array}{l}\text { Mahda- } \\
\text { linovka }\end{array}$ & $\begin{array}{l}48^{\circ} 43^{\prime} 46.0^{\prime} \mathrm{N} \\
35^{\circ} 00^{\prime} 31.0^{\prime \prime} \mathrm{E}\end{array}$ & loam & 2.08 & 8.10 & 0 & 4 & 1 & 0 & $20(11 f, 9 m)$ \\
\hline 7 & Pavlograd & $\begin{array}{l}48^{\circ} 34^{\prime} 24.0^{\prime \prime} \mathrm{N} \\
35^{\circ} 52^{\prime} 13.1^{\prime \prime} \mathrm{E}\end{array}$ & sandy loam & 2.13 & 7.98 & 0 & 0 & 2 & 2 & $35(21 \mathrm{f}, 14 \mathrm{~m})$ \\
\hline 8 & $\begin{array}{l}\text { Novo- } \\
\text { moskovsk }\end{array}$ & $\begin{array}{l}48^{\circ} 40^{\prime} 17.7^{\prime \prime} \mathrm{N} \\
35^{\circ} 18^{\prime} 37.3^{\prime \prime} \mathrm{E}\end{array}$ & loam & 3.22 & 7.75 & 0 & 2 & 0 & 0 & $37(20 \mathrm{f}, 17 \mathrm{~m})$ \\
\hline 9 & $\begin{array}{c}\text { Novo- } \\
\text { moskovsk }\end{array}$ & $\begin{array}{l}48^{\circ} 40^{\prime} 21.2^{\prime \prime} \mathrm{N} \\
35^{\circ} 21^{\prime} 19.5^{\prime \prime} \mathrm{E}\end{array}$ & loam & 3.48 & 7.99 & $\begin{array}{c}\text { 90\%: Typha angustifolia } \mathrm{L} . \\
(90 \%)\end{array}$ & 2 & 1 & 1 & $40(25 \mathrm{f}, 15 \mathrm{~m})$ \\
\hline 10 & Pavlograd & $\begin{array}{l}48^{\circ} 34^{\prime} 18.3^{\prime \prime} \mathrm{N} \\
35^{\circ} 51^{\prime} 57.1^{\prime \prime} \mathrm{E}\end{array}$ & sand & 4.40 & 7.75 & 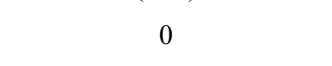 & 0 & 2 & 2 & $37(22 \mathrm{f}, 15 \mathrm{~m})$ \\
\hline 11 & Pavlograd & $\begin{array}{l}48^{\circ} 28^{\prime} 40.1^{\prime \prime} \mathrm{N} \\
36^{\circ} 01^{\prime} 21.8^{\prime \prime} \mathrm{E}\end{array}$ & loam & 4.42 & 7.98 & $\begin{array}{l}35 \% \text { : Chenopodium album L. } \\
\quad(30 \%) \text {, Poa sp. }(5 \%)\end{array}$ & 0 & 1 & 1 & $21(16 \mathrm{f}, 5 \mathrm{~m})$ \\
\hline 12 & $\begin{array}{c}\text { Novo- } \\
\text { moskovsk }\end{array}$ & $\begin{array}{l}48^{\circ} 37^{\prime} 32.9^{\prime \prime} \mathrm{N} \\
35^{\circ} 20^{\prime} 20.8^{\prime \prime} \mathrm{E}\end{array}$ & loam & 5.50 & 8.50 & 0 & 0 & 3 & 1 & $36(18 \mathrm{f}, 18 \mathrm{~m})$ \\
\hline
\end{tabular}

Notes: * - recreational load: 0 - absent (there are no human traces and household waste), 1 - slight (human traces and household waste are rare), 2 - medium (human traces and household waste occupy $10-30 \%$ of land area), 3 - high (human traces and household waste occupy more than $30 \%$ of land area); $* *$ - the effect of cattle grazing: 0 - absent (there are no animal trails and their feces), 1 - slight (animal trails and their feces are rare), 2 - medium (animal trails and their feces occupy 10-30\% of land area), 3 - strong (animal trails and their feces occupy more than $30 \%$ of land area); ${ }^{* * *}-\mathrm{f}-$ females, $\mathrm{m}-$ males.

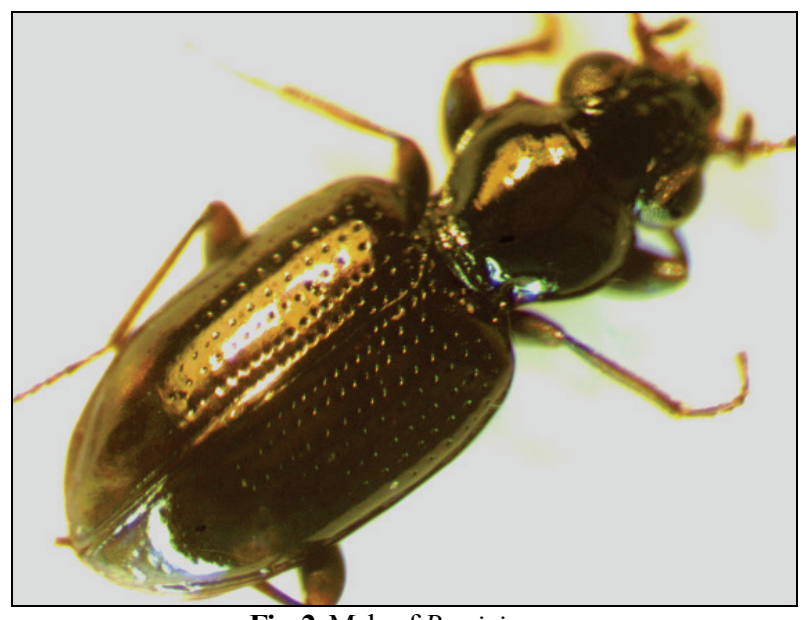

Fig. 2. Male of B. minimum

The results were processed by standard methods of variation statistics using Statistica software (version 8, StatSoft, USA). The effect of sex and environmental factors on morphological characteristics and indices was evaluated using MANOVA. Factor analysis was used to determine the similarity of morphological parameters and indices.

\section{Results}

The herb layer (Table 3) significantly affects 7 of 16 characteristics (P - density of elytra puncturing, Lp, Sc, Sp2, Spm, B, K) and 3 of 6 morphometric indexes ((Sc+Sp+Se)/3Lb, Le/Lp and Spm/Sp2). The herb layer significantly affects the display of sexual dimorphism of almost all morphometric characteristics (except for B, P, K) and indexes (except for $(\mathrm{Sc}+\mathrm{Sp}+\mathrm{Se}) / 3 \mathrm{Lb}, \mathrm{Se} / \mathrm{Sp}, \mathrm{Spm} / \mathrm{Sp} 2)$. The interaction between the herb layer and the sex significantly affects Lp, Se and Se/Sp.

Litter thickness affects Sp1, P, K and Le/Lp (Table 4). Litter thickness affects the manifestation of sexual dimorphism for most of the morphological parameters (except for B and $\mathrm{K}$ ) and indices (except for
$\mathrm{Lp} / \mathrm{Sp}, \mathrm{Se} / \mathrm{Sp}, \mathrm{Spm} / \mathrm{Sp} 2)$. The interaction of the litter thickness and the sex does not significantly affect any of the studied parameters.

Mechanical composition of soil (Table 5) significantly affects Lc and $\mathrm{Se} / \mathrm{Sp}, \mathrm{Lb}$. Sex does not affect any characteristics except B, Lp/Sp, $\mathrm{Spm} / \mathrm{Sp} 2$. The interaction of the mechanical composition of soil and sex does not significantly affect any of the studied characteristics (Table 5).

Soil mineralization (Table 6) significantly affects Lb, Lc, Lp, Sp1, $\mathrm{Sp} 2$, Se, B and P. Sex in the gradient of soil mineralization does not affect B, Se/Sp and Spm/Sp2. The interaction of soil mineralization and sex significantly affects Le and Spm.

Soil acidity (Table 7) significantly affects Lb, Lc, Le, Sc, Sp1, Sp2, Spm, Se, B, P, K, L21, $(\mathrm{Sc}+\mathrm{Sp}+\mathrm{Se}) / 3 \mathrm{Lb}$. Sex differences in the soil acidity gradient do not appear for B, Lp/Sp, Se/Sp and Spm/Sp2. The interaction of soil acidity and sex significantly affects $\mathrm{Lp} / \mathrm{Sp}$ and $\mathrm{Le} / \mathrm{Lp}$ (Table 7). Recreational load (Table 8) significantly affects Lb, Lc, Le, Sc, Sp1, Sp2, Spm, Se, B, P, K, L21, L2r, Lp/Sp, Le/Lp. Sex does not affect only B, Lp/Sp, Se/Sp and Spm/Sp2. The interaction of recreational load and sex (Table 8) significantly affects Lb, Le, Sc, Se, L11, L1r and $\mathrm{Se} / \mathrm{Sp}$. Cattle grazing (Table 9) significantly causes changes in all characteristics except L11, L1r, Se / Sp, Spm/Sp2, and Le/Se. The impact of sex does not significantly affect B, Lp/Sp, Se/Sp, Spm/Sp2. The interaction of cattle grazing and sex is not significant for any studied characteristics except Lp/Sp, Le/Lp.

In outermost variants of the herb layer (Fig. 3) - at high values $(70 \%)$ and the absence of herb layer $(0 \%)$ - the variability of most studied morphometric characteristics of B. minimum is far lower than with average values of herb layer (35\%). The maximum similarity between the studied features of females and males was registered for B (Fig. $3 g$ ), P (Fig. 3n), K (Fig. 3o) and all studied morphometric indices (Fig. 3q-v): $(\mathrm{Sc}+\mathrm{Sp}+\mathrm{Se}) / 3 \mathrm{Lb}, \mathrm{Lp} / \mathrm{Sp}, \mathrm{Le} / \mathrm{Lp}, \mathrm{Se} / \mathrm{Sp}, \mathrm{Spm} / \mathrm{Sp} 2, \mathrm{Le} / \mathrm{Se}$.

Depending on the litter thickness (Fig. 4), with its increase from 0 to 2 and $4 \mathrm{~cm}$, there is a tendency to a decrease in Le (from 1.62 to $1.60 \mathrm{~mm}$ in females and from 1.49 to $1.47 \mathrm{~mm}$ in males - Fig. $4 i$ ), $\mathrm{P}$ (from 239 to 212 in males and from 226 to 207 in females - Fig. 4n) and Le/Se (from 1.493 to 1.487 in males and from 1.518 to 1.500 in females - Fig. $4 v$ ). 
Table 2

Brief description of morphometric characteristics and indices used to assess variability of $B$. minimum populations

\begin{tabular}{|c|c|c|}
\hline $\begin{array}{l}\text { Morphological } \\
\text { characteristic } \\
\text { or indexes } \\
\end{array}$ & $\begin{array}{l}\text { Unit of } \\
\text { measu- } \\
\text { rement }\end{array}$ & Description \\
\hline $\mathrm{Lb}$ & $\mathrm{mm}$ & length of body \\
\hline $\mathrm{Lc}$ & $\mathrm{mm}$ & $\begin{array}{l}\text { length of head (from front edge of clypeus to articulation } \\
\text { with prothorax) }\end{array}$ \\
\hline Lp & $\mathrm{mm}$ & length of prothorax \\
\hline Le & $\mathrm{mm}$ & length of elytra \\
\hline $\mathrm{Sc}$ & $\mathrm{mm}$ & width of head with eyes \\
\hline Sp1 & $\mathrm{mm}$ & width of prothorax between front angles \\
\hline Sp2 & $\mathrm{mm}$ & width of prothorax between back angles \\
\hline Spm & $\mathrm{mm}$ & maximum width of prothorax \\
\hline $\mathrm{Se}$ & $\mathrm{mm}$ & $\begin{array}{l}\text { maximum width of elytra } \\
\text { the back angles of prothorax were determined on the left }\end{array}$ \\
\hline B & degree $^{0}$ & $\begin{array}{l}\text { (B1) and right (B2) parts of the body; for the further calcula- } \\
\text { tions, their arithmetic mean value was used }\end{array}$ \\
\hline$P$ & $\begin{array}{l}\text { units } \\
\text { per } \\
\mathrm{mm}^{2}\end{array}$ & $\begin{array}{l}\text { density of elytra puncturing was assessed from photographs } \\
\text { by counting the quantity of pores on the area } 1 \mathrm{~mm}^{2} \\
\text { between the back edge of the scutellar groove and the first } \\
\text { groove of the elytra }\end{array}$ \\
\hline K & $\begin{array}{c}\text { conven- } \\
\text { tional } \\
\text { units }\end{array}$ & $\begin{array}{l}\text { the contrast of the light spots at the top of the left }(\mathrm{Kl}) \text { and } \\
\text { right elytra }(\mathrm{Kr}) \text { was determined in a gradient from } 1 \text { (clear) } \\
\text { to } 4 \text { (poorly discernible), and their arithmetic mean value } \\
\text { was calculated for each beetle }\end{array}$ \\
\hline L11 & $\mathrm{mm}$ & distance from the base of the left elytra to the first setae \\
\hline L1r & $\mathrm{mm}$ & distance from the base of the right elytra to the first setae \\
\hline L21 & $\mathrm{mm}$ & distance between setae on the left elytra \\
\hline L2r & $\mathrm{mm}$ & distance between setae on the right elytra \\
\hline $\begin{array}{l}(\mathrm{Sc}+\mathrm{Sp}+\mathrm{Se}) / \\
3 \mathrm{Lb}\end{array}$ & - & $\begin{array}{l}\text { ratio of arithmetic mean value of the width of head, } \\
\text { prothorax and elytra to body length }\end{array}$ \\
\hline $\mathrm{Lp} / \mathrm{Sp}$ & - & ratio of prothorax length to its maximum width \\
\hline $\mathrm{Le} / \mathrm{Lp}$ & - & ratio of elytra length to prothorax length \\
\hline $\mathrm{Se} / \mathrm{Sp}$ & - & $\begin{array}{l}\text { ratio of maximum width of elytra to maximum prothorax } \\
\text { width }\end{array}$ \\
\hline $\mathrm{Spm} / \mathrm{Sp} 2$ & - & $\begin{array}{l}\text { ratio of maximum prothorax width to its width at the back } \\
\text { edge }\end{array}$ \\
\hline Le/Se & - & ratio of elytra length to their width \\
\hline
\end{tabular}

Note: linear characteristics were measured with an accuracy of \pm 1 pixel $(0.96 \mu \mathrm{m})$; accuracy of photographic measurement of angles was equal to $\pm 0.1^{\circ}$.

Table 3

MANOVA results of effect of herb layer

on morphometric variability of $B$. minimum populations

\begin{tabular}{|c|c|c|c|c|c|c|}
\hline \multirow{2}{*}{$\begin{array}{l}\text { Morphological } \\
\text { characteristic } \\
\text { or index }\end{array}$} & \multicolumn{2}{|c|}{ Factor } & \multicolumn{2}{|c|}{ Sex } & \multicolumn{2}{|c|}{ Factor* sex } \\
\hline & $\mathrm{F}$ & $P$ & $\mathrm{~F}$ & $P$ & $\mathrm{~F}$ & $\mathrm{P}$ \\
\hline $\mathrm{Lb}$ & 0.59 & 0.5522 & 55.40 & $<0.0001$ & 2.01 & 0.1354 \\
\hline $\mathrm{Lc}$ & 1.58 & 0.2072 & 23.39 & $<0.0001$ & 0.53 & 0.5895 \\
\hline $\mathrm{Lp}$ & 5.06 & 0.0068 & 11.75 & 0.0007 & 3.72 & 0.0250 \\
\hline Le & 0.30 & 0.7375 & 43.79 & $<0.0001$ & 1.69 & 0.1857 \\
\hline $\mathrm{Sc}$ & 3.63 & 0.0285 & 27.22 & $<0.0001$ & 1.42 & 0.2426 \\
\hline Sp1 & 1.89 & 0.1526 & 42.72 & $<0.0001$ & 0.39 & 0.6761 \\
\hline $\mathrm{Sp} 2$ & 7.83 & 0.0005 & 32.98 & $<0.0001$ & 0.07 & 0.9315 \\
\hline Spm & 4.39 & 0.0129 & 34.00 & $<0.0001$ & 0.33 & 0.7174 \\
\hline $\mathrm{Se}$ & 2.81 & 0.0612 & 27.64 & $<0.0001$ & 3.20 & 0.0419 \\
\hline B & 3.52 & 0.0305 & 1.67 & 0.1976 & 1.71 & 0.1816 \\
\hline $\mathrm{P}$ & 10.37 & $<0.0001$ & 2.98 & 0.0851 & 0.06 & 0.9437 \\
\hline $\mathrm{K}$ & 5.64 & 0.0039 & 0.05 & 0.8273 & 0.97 & 0.3810 \\
\hline L11 & 0.63 & 0.5357 & 13.67 & 0.0002 & 0.91 & 0.4037 \\
\hline L1r & 0.27 & 0.7656 & 18.82 & $<0.0001$ & 1.15 & 0.3176 \\
\hline L21 & 0.63 & 0.5335 & 23.95 & $<0.0001$ & 1.60 & 0.2022 \\
\hline $\mathrm{L} 2 \mathrm{r}$ & 0.98 & 0.3768 & 21.82 & $<0.0001$ & 2.00 & 0.1367 \\
\hline$(\mathrm{Sc}+\mathrm{Sp}+\mathrm{Se}) / 3 \mathrm{Lb}$ & 4.29 & 0.0145 & 3.81 & 0.0519 & 0.12 & 0.9324 \\
\hline $\mathrm{Lp} / \mathrm{Sp}$ & 0.06 & 0.9446 & 5.70 & 0.0174 & 2.53 & 0.0809 \\
\hline $\mathrm{Le} / \mathrm{Lp}$ & 3.50 & 0.0312 & 11.13 & 0.0009 & 0.57 & 0.5635 \\
\hline $\mathrm{Se} / \mathrm{Sp}$ & 1.81 & 0.1714 & 3.02 & 0.0862 & 4.69 & 0.0099 \\
\hline $\mathrm{Spm} / \mathrm{Sp} 2$ & 3.12 & 0.0450 & 0.70 & 0.4035 & 0.94 & 0.3919 \\
\hline $\mathrm{Le} / \mathrm{Se}$ & 2.40 & 0.0924 & 7.73 & 0.0057 & 0.31 & 0.7345 \\
\hline
\end{tabular}

Note: names of characteristics are given in section Materials and Methods.

Depending on the mechanical composition of the soil, B. minimum head length Lc increases (from 0.393 on sandy to $0.407 \mathrm{~mm}$ on loamy soils in females and from 0.363 on sandy to $0.382 \mathrm{~mm}$ on loamy soils in males - Fig. $5 a$ ) and Sp2/Spm index (from 0.647 on sandy to 0.655 on loamy soils in females and from 0.650 on sandy to 0.657 on loamy soils in males - Fig. $5 u$ ).

\section{Table 4}

MANOVA results of effect of litter thickness on morphometric variability of $B$. minimum populations

\begin{tabular}{|c|c|c|c|c|c|c|}
\hline \multirow{2}{*}{$\begin{array}{l}\text { Morphological } \\
\text { characteristic } \\
\text { or index }\end{array}$} & \multicolumn{2}{|c|}{ Factor } & \multicolumn{2}{|c|}{ Sex } & \multicolumn{2}{|c|}{ Factor* sex } \\
\hline & $\mathrm{F}$ & $\mathrm{P}$ & $\mathrm{F}$ & $\mathrm{P}$ & $\mathrm{F}$ & $P$ \\
\hline $\mathrm{Lb}$ & 1.18 & 0.3069 & 197.64 & $<0.0001$ & 0.33 & 0.7468 \\
\hline $\mathrm{Lc}$ & 2.61 & 0.0748 & 46.20 & $<0.0001$ & 0.25 & 0.7811 \\
\hline Lp & 2.68 & 0.0699 & 78.13 & $<0.0001$ & 0.52 & 0.5941 \\
\hline Le & 1.81 & 0.1654 & 153.39 & $<0.0001$ & 0.47 & 0.6255 \\
\hline $\mathrm{Sc}$ & 0.19 & 0.7794 & 108.87 & $<0.0001$ & 0.82 & 0.4626 \\
\hline Sp1 & 3.03 & 0.0487 & 113.62 & $<0.0001$ & 0.29 & 0.7263 \\
\hline $\mathrm{Sp} 2$ & 0.08 & 0.9189 & 76.95 & $<0.0001$ & 0.20 & 0.8200 \\
\hline Spm & 0.50 & 0.6065 & 106.67 & $<0.0001$ & 0.85 & 0.4301 \\
\hline $\mathrm{Se}$ & 0.48 & 0.6062 & 126.79 & $<0.0001$ & 0.61 & 0.5480 \\
\hline B & 2.35 & 0.0967 & 0.68 & 0.4087 & 1.33 & 0.2657 \\
\hline $\mathrm{P}$ & 15.74 & $<0.0001$ & 6.47 & 0.0113 & 0.24 & 0.7852 \\
\hline $\mathrm{K}$ & 3.96 & 0.0197 & 3.03 & 0.0824 & 0.36 & 0.7006 \\
\hline L11 & 0.91 & 0.4037 & 44.29 & $<0.0001$ & 0.93 & 0.3941 \\
\hline L1r & 1.34 & 0.2627 & 45.56 & $<0.0001$ & 1.97 & 0.1404 \\
\hline L21 & 0.27 & 0.7613 & 96.28 & $<0.0001$ & 0.05 & 0.9484 \\
\hline $\mathrm{L} 2 \mathrm{r}$ & 0.73 & 0.4836 & 99.21 & $<0.0001$ & 0.44 & 0.6431 \\
\hline$(\mathrm{Sc}+\mathrm{Sp}+\mathrm{Se}) / 3 \mathrm{Lb}$ & 0.72 & 0.5202 & 6.54 & 0.0112 & 0.47 & 0.6014 \\
\hline $\mathrm{Lp} / \mathrm{Sp}$ & 2.43 & 0.0925 & 1.09 & 0.3051 & 0.14 & 0.9269 \\
\hline $\mathrm{Le} / \mathrm{Lp}$ & 3.69 & 0.0257 & 11.23 & 0.0008 & 0.71 & 0.4898 \\
\hline $\mathrm{Se} / \mathrm{Sp}$ & 0.12 & 0.9118 & 0.47 & 0.4910 & 0.62 & 0.5420 \\
\hline $\mathrm{Spm} / \mathrm{Sp} 2$ & 1.03 & 0.3524 & 0.21 & 0.6305 & 0.60 & 0.5435 \\
\hline $\mathrm{Le} / \mathrm{Se}$ & 1.13 & 0.3397 & 8.38 & 0.0039 & 0.31 & 0.7394 \\
\hline
\end{tabular}

Table 5

MANOVA results of effect of mechanical composition of soil on morphometric variability of B. minimum populations

\begin{tabular}{|c|c|c|c|c|c|c|}
\hline \multirow{2}{*}{$\begin{array}{l}\text { Morphological } \\
\text { characteristic } \\
\text { or index }\end{array}$} & \multicolumn{2}{|c|}{ Factor } & \multicolumn{2}{|c|}{ Sex } & \multicolumn{2}{|c|}{ Factor* sex } \\
\hline & $\mathrm{F}$ & $\mathrm{P}$ & $\mathrm{F}$ & $\mathrm{P}$ & $\mathrm{F}$ & $\mathrm{P}$ \\
\hline $\mathrm{Lb}$ & 3.24 & 0.0428 & 236.51 & $<0.0001$ & 0.92 & 0.4087 \\
\hline Lc & 9.37 & 0.0001 & 53.38 & $<0.0001$ & 2.14 & 0.1185 \\
\hline Lp & 0.71 & 0.4843 & 80.19 & $<0.0001$ & 0.04 & 0.9948 \\
\hline Le & 1.19 & 0.3037 & 189.22 & $<0.0001$ & 0.47 & 0.5953 \\
\hline $\mathrm{Sc}$ & 1.40 & 0.2542 & 117.23 & $<0.0001$ & 0.58 & 0.5750 \\
\hline Sp1 & 0.11 & 0.9098 & 134.13 & $<0.0001$ & 1.52 & 0.2159 \\
\hline $\mathrm{Sp} 2$ & 2.82 & 0.0607 & 83.18 & $<0.0001$ & 0.68 & 0.5075 \\
\hline Spm & 1.02 & 0.3829 & 113.46 & $<0.0001$ & 1.50 & 0.2249 \\
\hline $\mathrm{Se}$ & 2.04 & 0.1354 & 154.71 & $<0.0001$ & 1.21 & 0.2959 \\
\hline B & 2.29 & 0.1026 & 0.04 & 0.8412 & 0.29 & 0.7485 \\
\hline $\mathrm{P}$ & 0.47 & 0.6266 & 11.23 & 0.0009 & 0.99 & 0.3714 \\
\hline $\mathrm{K}$ & 1.69 & 0.1859 & 8.53 & 0.0037 & 1.32 & 0.2684 \\
\hline L11 & 0.09 & 0.9106 & 46.30 & $<0.0001$ & 0.30 & 0.7382 \\
\hline L1r & 0.12 & 0.8905 & 67.11 & $<0.0001$ & 0.43 & 0.6481 \\
\hline L21 & 2.10 & 0.1243 & 112.25 & $<0.0001$ & 0.56 & 0.5724 \\
\hline $\mathrm{L} 2 \mathrm{r}$ & 2.42 & 0.0906 & 115.30 & $<0.0001$ & 1.21 & 0.2992 \\
\hline$(\mathrm{Sc}+\mathrm{Sp}+\mathrm{Se}) / 3 \mathrm{Lb}$ & 0.80 & 0.4665 & 10.57 & 0.0012 & 0.09 & 0.8680 \\
\hline $\mathrm{Lp} / \mathrm{Sp}$ & 0.05 & 0.9878 & 1.20 & 0.2720 & 1.51 & 0.2291 \\
\hline $\mathrm{Le} / \mathrm{Lp}$ & 1.42 & 0.2584 & 20.93 & $<0.0001$ & 0.59 & 0.5734 \\
\hline $\mathrm{Se} / \mathrm{Sp}$ & 3.54 & 0.0319 & 4.52 & 0.0353 & 1.24 & 0.2954 \\
\hline $\mathrm{Spm} / \mathrm{Sp} 2$ & 1.90 & 0.1499 & 0.21 & 0.6648 & 0.10 & 0.8865 \\
\hline $\mathrm{Le} / \mathrm{Se}$ & 0.13 & 0.8663 & 11.52 & 0.0008 & 0.19 & 0.7944 \\
\hline
\end{tabular}

Soil mineralization is one of the most significant environmental parameters for invertebrates living on salt marshes: mineralization of the soil solution is less than $3 \mathrm{~g} / \mathrm{L}$. With an increase in mineralization of the soil solution, there is a tendency toward an increase in head width in females and a decrease in this parameter in males (Fig. $6 b$ ). The prothorax width between its front angles in males decreases with increasing mineralization (Fig. 6d). The prothorax width between back angles and its maximum width tends to increase in females on highly mineralized soils (Fig. 6e,f). Similar changes were registered for length and width of the elytra in females (Fig. 6h, $i$ ). There is also a tendency (in both males and females) to decrease in density of elytra puncturing (from 217-245 
to $208-209$ pores on the area $1 \mathrm{~mm}^{2}-$ Fig. $6 n$ ) in areas with high mineralization of the soil. A tendency to increase in the body length of females was revealed, in contrast to males, in areas with saline soil (Fig. 6p). The ratio of prothotax length to maximum width $(\mathrm{Lp} / \mathrm{Sp}$, Fig. $6 r)$ and also the ratio of the elytra length to prothorax length (Le/Lp, Fig. 6s) tend to increase in males of $B$. minimum.

\section{Table 6}

MANOVA results of effect of soil mineralization on morphometric variability of B. minimum populations

\begin{tabular}{|c|c|c|c|c|c|c|}
\hline \multirow{2}{*}{$\begin{array}{c}\text { Morphological } \\
\text { characteristic } \\
\text { or index }\end{array}$} & \multicolumn{2}{|c|}{ Factor } & \multicolumn{2}{|c|}{ Sex } & \multicolumn{2}{|c|}{ Factor* sex } \\
\hline & $\mathrm{F}$ & $P$ & $\mathrm{~F}$ & $\mathrm{P}$ & $\mathrm{F}$ & $\mathrm{P}$ \\
\hline $\mathrm{Lb}$ & 3.51 & 0.0042 & 313.43 & $<0.0001$ & 2.04 & 0.0741 \\
\hline $\mathrm{Lc}$ & 7.40 & $<0.0001$ & 67.42 & $<0.0001$ & 0.61 & 0.6892 \\
\hline Lp & 2.92 & 0.0138 & 103.30 & $<0.0001$ & 0.89 & 0.5041 \\
\hline Le & 1.53 & 0.1774 & 251.79 & $<0.0001$ & 2.54 & 0.0318 \\
\hline $\mathrm{Sc}$ & 1.93 & 0.0861 & 159.02 & $<0.0001$ & 1.69 & 0.1393 \\
\hline Sp1 & 3.58 & 0.0031 & 162.62 & $<0.0001$ & 0.78 & 0.5198 \\
\hline $\mathrm{Sp} 2$ & 2.56 & 0.0271 & 118.90 & $<0.0001$ & 1.52 & 0.2008 \\
\hline Spm & 1.72 & 0.1386 & 162.11 & $<0.0001$ & 2.18 & 0.0500 \\
\hline $\mathrm{Se}$ & 2.39 & 0.0359 & 201.52 & $<0.0001$ & 2.23 & 0.0557 \\
\hline $\mathrm{B}$ & 4.51 & 0.0005 & 0.13 & 0.8157 & 1.34 & 0.2795 \\
\hline $\mathrm{P}$ & 5.32 & 0.0001 & 8.04 & 0.0048 & 1.08 & 0.3733 \\
\hline $\mathrm{K}$ & 1.88 & 0.0971 & 4.83 & 0.0285 & 0.53 & 0.7551 \\
\hline L11 & 0.89 & 0.4881 & 63.18 & $<0.0001$ & 1.16 & 0.3275 \\
\hline L1r & 0.96 & 0.4449 & 88.23 & $<0.0001$ & 2.17 & 0.0568 \\
\hline L21 & 1.43 & 0.2138 & 139.94 & $<0.0001$ & 0.59 & 0.7068 \\
\hline $\mathrm{L} 2 \mathrm{r}$ & 1.62 & 0.1522 & 125.95 & $<0.0001$ & 0.36 & 0.8774 \\
\hline$(\mathrm{Sc}+\mathrm{Sp}+\mathrm{Se}) / 3 \mathrm{Lb}$ & 1.04 & 0.4222 & 11.01 & 0.0010 & 0.38 & 0.8640 \\
\hline $\mathrm{Lp} / \mathrm{Sp}$ & 1.23 & 0.2869 & 3.92 & 0.0481 & 1.57 & 0.1649 \\
\hline $\mathrm{Le} / \mathrm{Lp}$ & 1.50 & 0.1924 & 29.04 & $<0.0001$ & 1.40 & 0.2194 \\
\hline $\mathrm{Se} / \mathrm{Sp}$ & 1.52 & 0.1880 & 1.63 & 0.2105 & 0.29 & 0.9018 \\
\hline $\mathrm{Spm} / \mathrm{Sp} 2$ & 1.48 & 0.2018 & 0.13 & 0.7221 & 0.72 & 0.6184 \\
\hline $\mathrm{Le} / \mathrm{Se}$ & 0.82 & 0.5422 & 16.60 & $<0.0001$ & 0.11 & 0.9879 \\
\hline
\end{tabular}

\section{Table 7}

MANOVA results of effect of soil acidity

on morphometric variability of $B$. minimum populations

\begin{tabular}{|c|c|c|c|c|c|c|}
\hline \multirow{2}{*}{$\begin{array}{l}\text { Morphological } \\
\text { characteristic } \\
\text { or index }\end{array}$} & \multicolumn{2}{|c|}{ Factor } & \multicolumn{2}{|c|}{ Sex } & \multicolumn{2}{|c|}{ Factor*sex } \\
\hline & $\mathrm{F}$ & $\mathrm{P}$ & $\mathrm{F}$ & $P$ & $\mathrm{~F}$ & $\mathrm{P}$ \\
\hline $\mathrm{Lb}$ & 4.02 & 0.0032 & 307.86 & $<0.0001$ & 1.29 & 0.2723 \\
\hline $\mathrm{Lc}$ & 3.98 & 0.0036 & 64.66 & $<0.0001$ & 1.45 & 0.2172 \\
\hline $\mathrm{Lp}$ & 1.83 & 0.1354 & 106.74 & $<0.0001$ & 1.49 & 0.1931 \\
\hline Le & 3.94 & 0.0037 & 248.71 & $<0.0001$ & 1.36 & 0.2437 \\
\hline $\mathrm{Sc}$ & 6.31 & $<0.0001$ & 165.60 & $<0.0001$ & 0.89 & 0.4659 \\
\hline Sp1 & 13.04 & $<0.0001$ & 179.58 & $<0.0001$ & 0.19 & 0.9500 \\
\hline $\mathrm{Sp} 2$ & 2.70 & 0.0328 & 103.54 & $<0.0001$ & 0.21 & 0.9105 \\
\hline Spm & 4.27 & 0.0022 & 156.63 & $<0.0001$ & 0.89 & 0.4528 \\
\hline $\mathrm{Se}$ & 6.11 & $<0.0001$ & 203.34 & $<0.0001$ & 1.83 & 0.1379 \\
\hline B & 4.58 & 0.0013 & 0.12 & 0.7599 & 0.31 & 0.8803 \\
\hline $\mathrm{P}$ & 20.32 & $<0.0001$ & 10.10 & 0.0016 & 1.49 & 0.2034 \\
\hline $\mathrm{K}$ & 7.36 & $<0.0001$ & 7.61 & 0.0061 & 0.98 & 0.4305 \\
\hline L11 & 1.67 & 0.1569 & 61.79 & $<0.0001$ & 0.59 & 0.6684 \\
\hline L1r & 0.77 & 0.5482 & 79.35 & $<0.0001$ & 0.78 & 0.5363 \\
\hline L21 & 2.54 & 0.0397 & 146.29 & $<0.0001$ & 2.16 & 0.0728 \\
\hline $\mathrm{L} 2 \mathrm{r}$ & 2.10 & 0.0803 & 139.69 & $<0.0001$ & 2.37 & 0.0518 \\
\hline$(\mathrm{Sc}+\mathrm{Sp}+\mathrm{Se}) / 3 \mathrm{Lb}$ & 2.67 & 0.0326 & 11.73 & 0.0007 & 0.40 & 0.8160 \\
\hline $\mathrm{Lp} / \mathrm{Sp}$ & 1.04 & 0.4223 & 2.10 & 0.1493 & 2.51 & 0.0399 \\
\hline $\mathrm{Le} / \mathrm{Lp}$ & 1.79 & 0.1332 & 25.11 & $<0.0001$ & 2.50 & 0.0424 \\
\hline $\mathrm{Se} / \mathrm{Sp}$ & 1.13 & 0.3364 & 2.27 & 0.1315 & 1.62 & 0.1839 \\
\hline $\mathrm{Spm} / \mathrm{Sp} 2$ & 0.81 & 0.5090 & 1.08 & 0.2912 & 1.70 & 0.1589 \\
\hline $\mathrm{Le} / \mathrm{Se}$ & 0.78 & 0.5578 & 15.83 & $<0.0001$ & 0.59 & 0.6305 \\
\hline
\end{tabular}

Decrease in the number of pores on the elytra in males and females was observed at the level of tendency in areas with more alkaline soils (Fig. $7 n$ ). The ratio of prothorax length to its maximum width increases in males, and it decreases in females in areas with higher $\mathrm{pH}$ of the soil solution (Lp/Sp, Fig. 7r). Opposite changes were noted for the ratio of elytra length to prothorax length (Le/Lp, Fig. $7 \mathrm{~s})$ : in areas with higher $\mathrm{pH}$ values this index decreases in males and increases in females. The maximum values of $\mathrm{Se} / \mathrm{Sp}$ index (Fig. $7 s$ ) were observed in females in areas with neutral soil solution; the minimum Sp2/Spm (Fig. $7 u$ ) was recorded in females of B. minimum in areas with more alkaline soil solution.

\section{Table 8}

MANOVA results of effect of recreational load

on morphometric variability of B. minimum populations

\begin{tabular}{|c|c|c|c|c|c|c|}
\hline \multirow{2}{*}{$\begin{array}{l}\text { Morphological } \\
\text { characteristic } \\
\text { or index }\end{array}$} & \multicolumn{2}{|c|}{ Factor } & \multicolumn{2}{|c|}{ Sex } & \multicolumn{2}{|c|}{ Factor* sex } \\
\hline & $\mathrm{F}$ & $\mathrm{P}$ & $\mathrm{F}$ & $\mathrm{P}$ & $\mathrm{F}$ & $\mathrm{P}$ \\
\hline $\mathrm{Lb}$ & 12.81 & $<0.0001$ & 312.16 & $<0.0001$ & 3.21 & 0.0238 \\
\hline Lc & 11.23 & $<0.0001$ & 66.94 & $<0.0001$ & 0.36 & 0.7830 \\
\hline Lp & 1.49 & 0.2042 & 99.21 & $<0.0001$ & 2.19 & 0.0832 \\
\hline Le & 15.84 & $<0.0001$ & 257.05 & $<0.0001$ & 3.52 & 0.0165 \\
\hline $\mathrm{Sc}$ & 12.10 & $<0.0001$ & 160.32 & $<0.0001$ & 4.23 & 0.0061 \\
\hline Sp1 & 16.59 & $<0.0001$ & 188.67 & $<0.0001$ & 2.18 & 0.0844 \\
\hline $\mathrm{Sp} 2$ & 6.52 & 0.0003 & 111.24 & $<0.0001$ & 0.91 & 0.4309 \\
\hline Spm & 6.87 & 0.0001 & 152.86 & $<0.0001$ & 2.30 & 0.0725 \\
\hline $\mathrm{Se}$ & 13.42 & $<0.0001$ & 198.85 & $<0.0001$ & 3.76 & 0.0099 \\
\hline B & 10.96 & $<0.0001$ & 0.43 & 0.5491 & 1.84 & 0.1534 \\
\hline $\mathrm{P}$ & 35.70 & $<0.0001$ & 9.09 & 0.0027 & 2.33 & 0.0736 \\
\hline $\mathrm{K}$ & 13.29 & $<0.0001$ & 8.59 & 0.0036 & 0.63 & 0.5972 \\
\hline L11 & 0.86 & 0.4623 & 57.27 & $<0.0001$ & 2.98 & 0.0313 \\
\hline L1r & 1.00 & 0.3937 & 75.37 & $<0.0001$ & 3.34 & 0.0194 \\
\hline L21 & 2.95 & 0.0324 & 139.10 & $<0.0001$ & 1.30 & 0.2692 \\
\hline $\mathrm{L} 2 \mathrm{r}$ & 3.78 & 0.0107 & 132.67 & $<0.0001$ & 1.23 & 0.2970 \\
\hline$(\mathrm{Sc}+\mathrm{Sp}+\mathrm{Se}) / 3 \mathrm{Lb}$ & 2.39 & 0.0699 & 12.36 & 0.0005 & 0.91 & 0.4573 \\
\hline $\mathrm{Lp} / \mathrm{Sp}$ & 3.50 & 0.0156 & 2.81 & 0.0959 & 2.53 & 0.0594 \\
\hline $\mathrm{Le} / \mathrm{Lp}$ & 10.01 & $<0.0001$ & 26.95 & $<0.0001$ & 1.01 & 0.4154 \\
\hline $\mathrm{Se} / \mathrm{Sp}$ & 2.38 & 0.0662 & 1.40 & 0.2433 & 3.62 & 0.0128 \\
\hline $\mathrm{Spm} / \mathrm{Sp} 2$ & 1.40 & 0.2404 & 0.24 & 0.6727 & 0.50 & 0.7063 \\
\hline $\mathrm{Le} / \mathrm{Se}$ & 1.32 & 0.2797 & 16.94 & $<0.0001$ & 0.11 & 0.9732 \\
\hline
\end{tabular}

Table 9

MANOVA results of effect of cattle grazing

on morphometric variability of $B$. minimum populations

\begin{tabular}{|c|c|c|c|c|c|c|}
\hline \multirow{2}{*}{$\begin{array}{l}\text { Morphological } \\
\text { characteristic } \\
\text { or index }\end{array}$} & \multicolumn{2}{|c|}{ Factor } & \multicolumn{2}{|c|}{ Sex } & \multicolumn{2}{|c|}{ Factor* sex } \\
\hline & $\mathrm{F}$ & $\mathrm{P}$ & $\mathrm{F}$ & $\mathrm{P}$ & $\mathrm{F}$ & $P$ \\
\hline $\mathrm{Lb}$ & 18.02 & $<0.0001$ & 343.17 & $<0.0001$ & 1.32 & 0.2855 \\
\hline $\mathrm{Lc}$ & 13.47 & $<0.0001$ & 63.90 & $<0.0001$ & 0.25 & 0.8603 \\
\hline Lp & 2.60 & 0.0490 & 109.06 & $<0.0001$ & 1.81 & 0.1428 \\
\hline Le & 20.95 & $<0.0001$ & 288.06 & $<0.0001$ & 1.39 & 0.2499 \\
\hline $\mathrm{Sc}$ & 13.72 & $<0.0001$ & 178.13 & $<0.0001$ & 2.50 & 0.0589 \\
\hline Sp1 & 10.79 & $<0.0001$ & 184.35 & $<0.0001$ & 2.02 & 0.1128 \\
\hline $\mathrm{Sp} 2$ & 8.03 & $<0.0001$ & 118.74 & $<0.0001$ & 0.93 & 0.4171 \\
\hline Spm & 9.74 & $<0.0001$ & 165.46 & $<0.0001$ & 1.50 & 0.2244 \\
\hline $\mathrm{Se}$ & 17.84 & $<0.0001$ & 221.87 & $<0.0001$ & 1.32 & 0.2783 \\
\hline B & 6.47 & 0.0003 & 0.01 & 0.9987 & 1.71 & 0.1685 \\
\hline $\mathrm{P}$ & 21.41 & $<0.0001$ & 8.14 & 0.0046 & 1.82 & 0.1437 \\
\hline K & 9.26 & $<0.0001$ & 9.23 & 0.0025 & 1.01 & 0.3907 \\
\hline L11 & 2.44 & 0.0636 & 69.16 & $<0.0001$ & 2.29 & 0.0776 \\
\hline L1r & 1.36 & 0.2556 & 86.42 & $<0.0001$ & 1.68 & 0.1716 \\
\hline L21 & 3.55 & 0.0145 & 143.21 & $<0.0001$ & 0.53 & 0.6596 \\
\hline $\mathrm{L} 2 \mathrm{r}$ & 5.12 & 0.0017 & 137.98 & $<0.0001$ & 1.28 & 0.2822 \\
\hline$(\mathrm{Sc}+\mathrm{Sp}+\mathrm{Se}) / 3 \mathrm{Lb}$ & 2.82 & 0.0410 & 12.14 & 0.0006 & 0.49 & 0.6982 \\
\hline $\mathrm{Lp} / \mathrm{Sp}$ & 2.70 & 0.0456 & 2.49 & 0.1171 & 4.03 & 0.0080 \\
\hline $\mathrm{Le} / \mathrm{Lp}$ & 8.13 & $<0.0001$ & 29.83 & $<0.0001$ & 2.78 & 0.0399 \\
\hline $\mathrm{Se} / \mathrm{Sp}$ & 2.12 & 0.0976 & 2.70 & 0.1020 & 2.29 & 0.0800 \\
\hline $\mathrm{Spm} / \mathrm{Sp} 2$ & 1.53 & 0.2101 & 0.31 & 0.5854 & 0.20 & 0.9235 \\
\hline $\mathrm{Le} / \mathrm{Se}$ & 0.80 & 0.4987 & 18.14 & $<0.0001$ & 0.59 & 0.6382 \\
\hline
\end{tabular}

In males the head width (Sc, Fig. 8b), the prothorax width between front (Sp1, Fig. 8d) and back angles (Sp2, Fig. 8e) and also its maximum width (Spm, Fig. 8f) decrease in areas with pronounced recreational load. There was a tendency to increase back angles of the protho$\operatorname{rax}(\mathrm{B}, \mathrm{Fig} .8 \mathrm{~g}$ ) in both males and females in areas with a recreational load. Recreation in littoral areas - habitats of B. minimum - causes a decrease in the elytra length (Le, Fig. $8 h$ ) in both males and females. Recreational load causes more pronounced decrease in the elytra width (Se, Fig. 8i) in males than in females. The distances to the first setae on the left and right elytra $(\mathrm{L} 11, \mathrm{~L} 1 \mathrm{r}, \mathrm{Fig} .8 k, m)$ in areas with a recreational load significantly decrease in males, but they inversely tend to increase in females. The number of pores per unit area of the elytra (P, Fig. $8 n$ ) decreases in both females and males with increasing degree of recreation. 

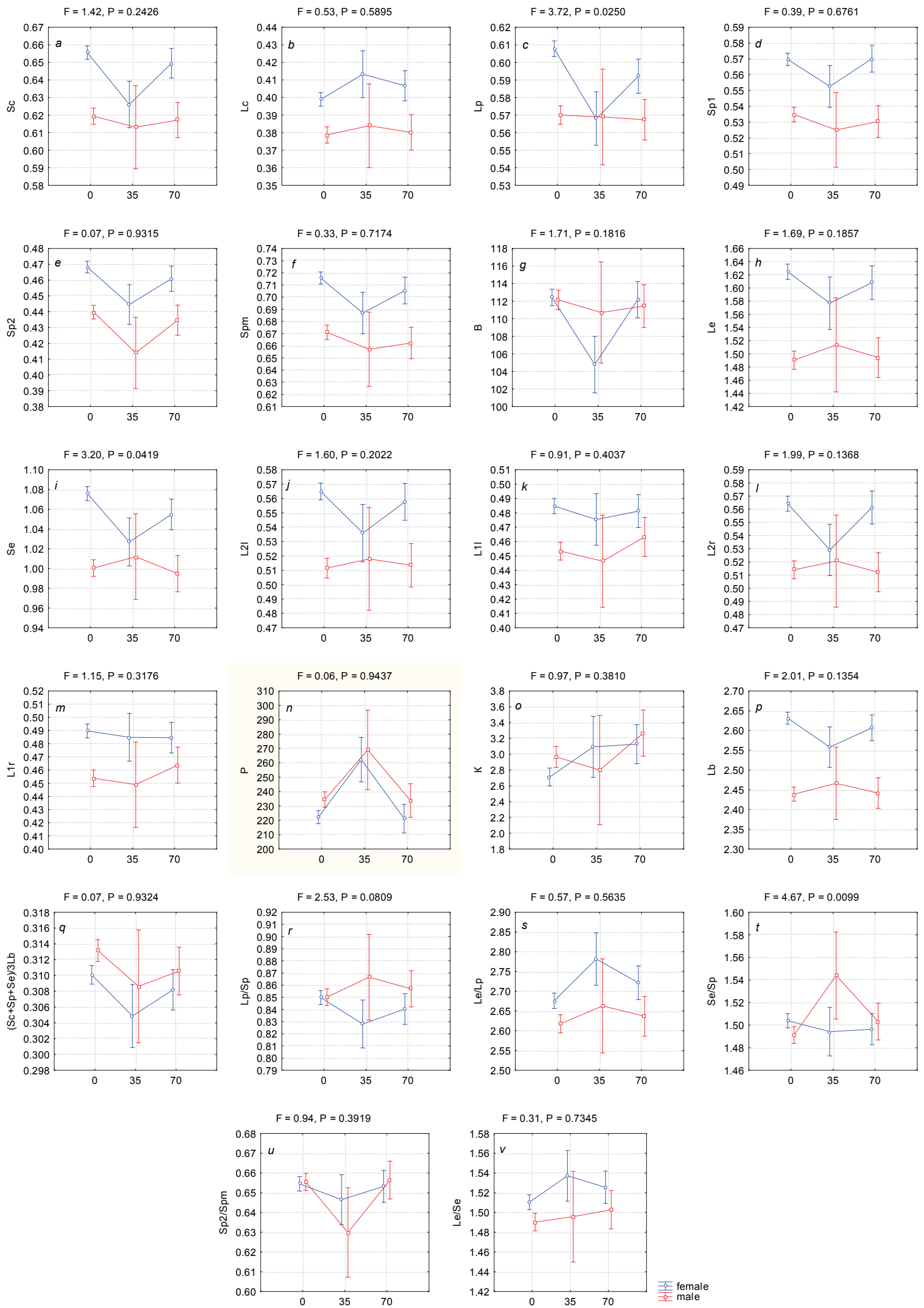

Fig. 3. Variability of morphometric characteristics of $B$. minimum body in studied populations depending on herb layer: on X axis: 0 - there is no herb layer, 35 - average herb layer is $35 \%, 70$ - average herb layer is $70 \%$; other notations see Table 2 

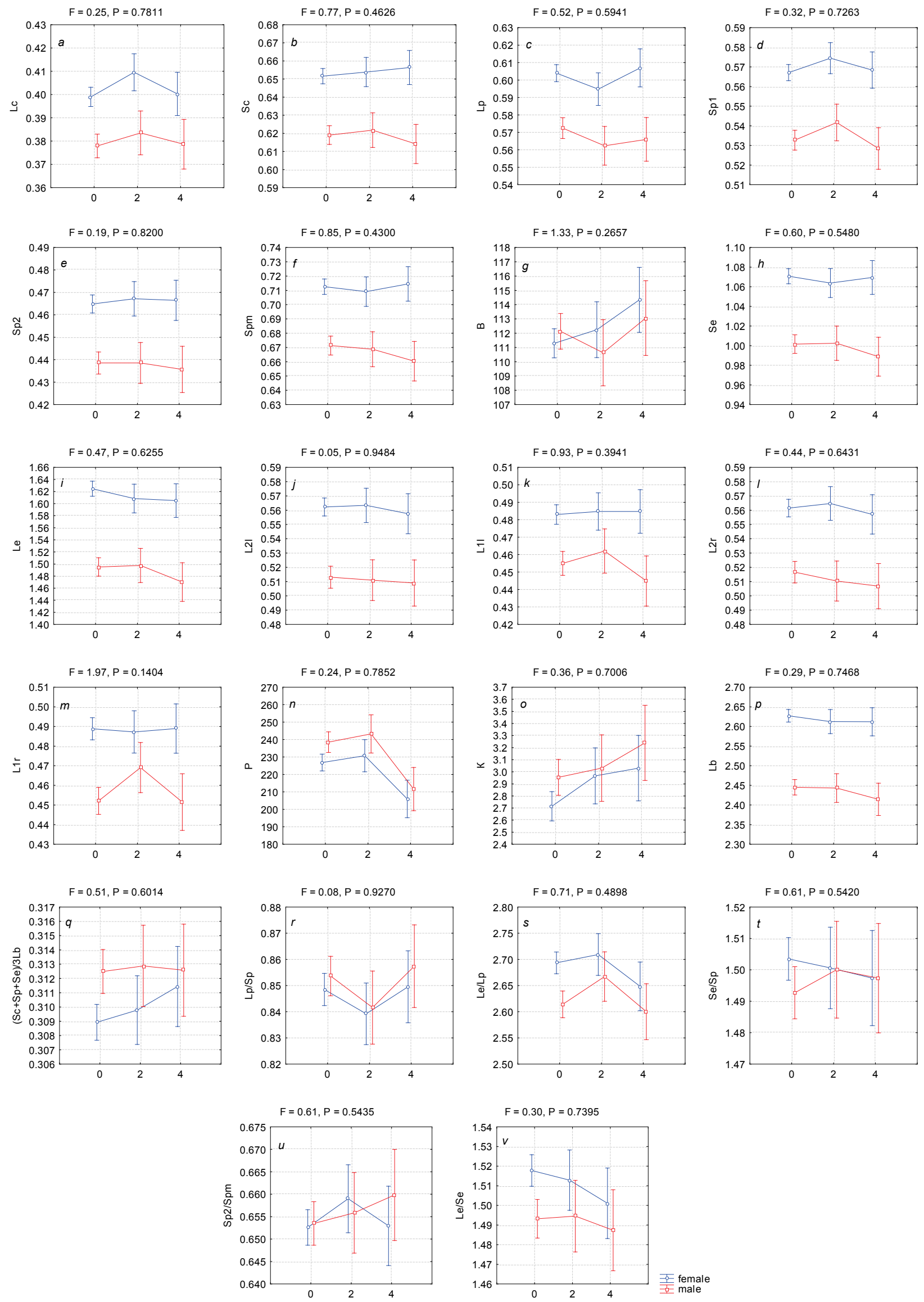

Fig. 4. Variability of morphometric characteristics of B. minimum body in studied populations depending on litter thickness: on X axis: 0 - there is no litter, 2 - litter thickness is $2 \mathrm{~cm}, 4$ - litter thickness is $4 \mathrm{~cm}$; other notations see Table 2 

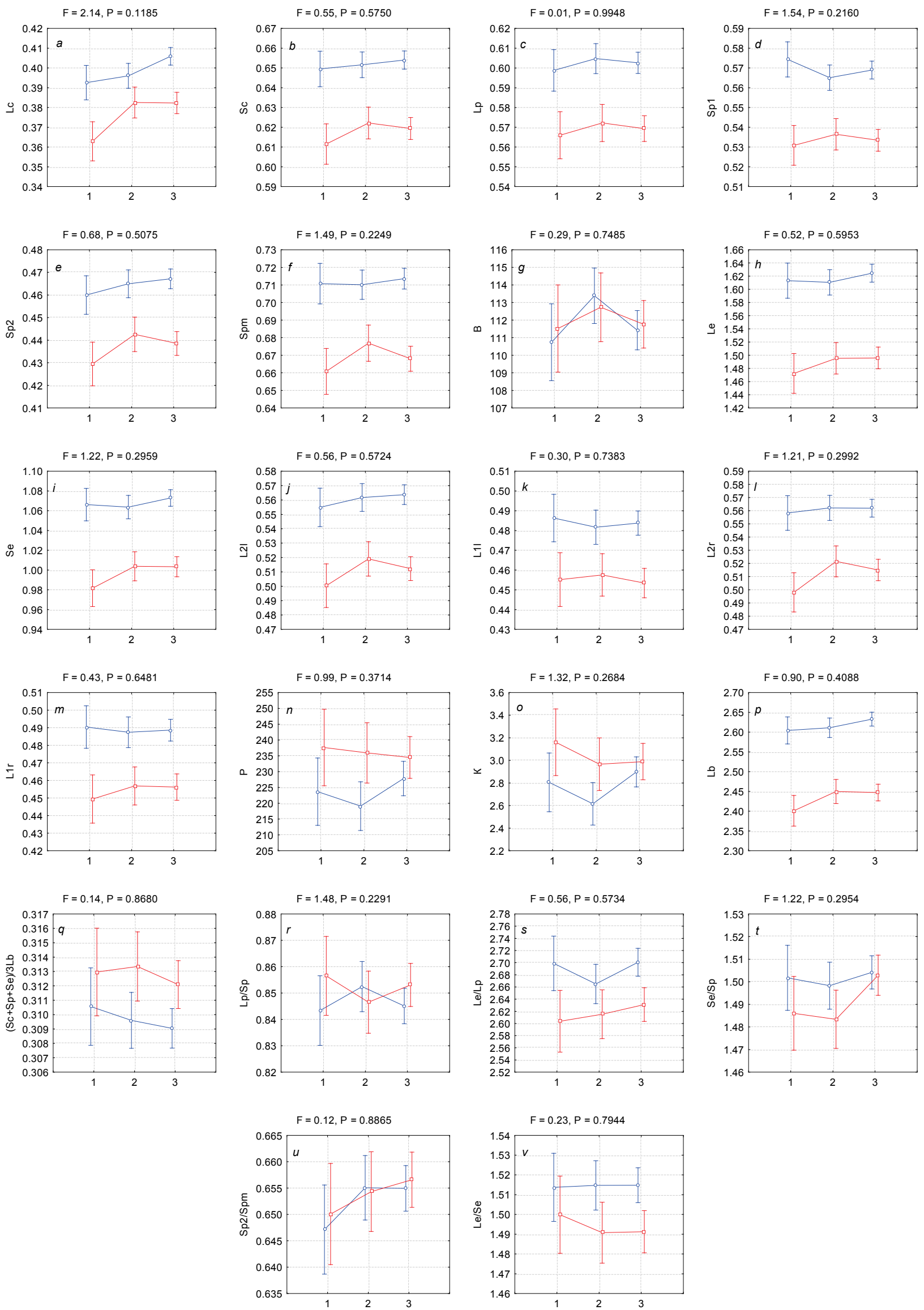

Fig. 5. Variability of morphometric characteristics of B. minimum body in studied populations depending on mechanical composition of soil: 1 - sand, 2 - sandy loam, 3 -loam; notations see Table 2 

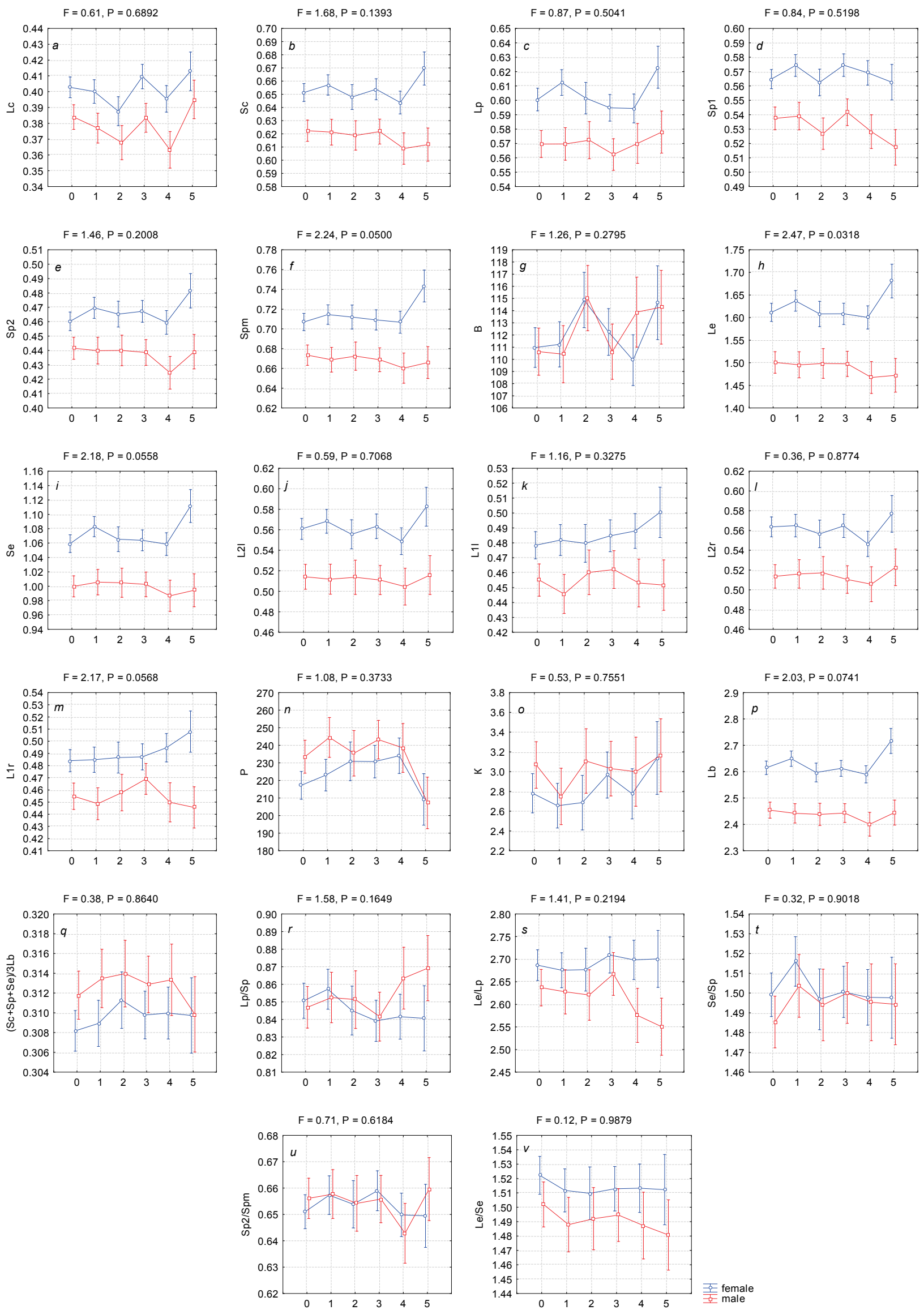

Fig. 6. Variability of morphometric characteristics of B. minimum body in studied populations depending on soil mineralization: on X axis: $0-0.0-1.0 \mathrm{~g} / \mathrm{L}, 1-1.0-2.0 \mathrm{~g} / \mathrm{L}, 2-2.0-3.0 \mathrm{~g} / \mathrm{L}, 3-3.0-4.0 \mathrm{~g} / \mathrm{L}, 4-4.0-5.0 \mathrm{~g} / \mathrm{L}, 5->5.0 \mathrm{~g} / \mathrm{L}$; other notations see Table 2 

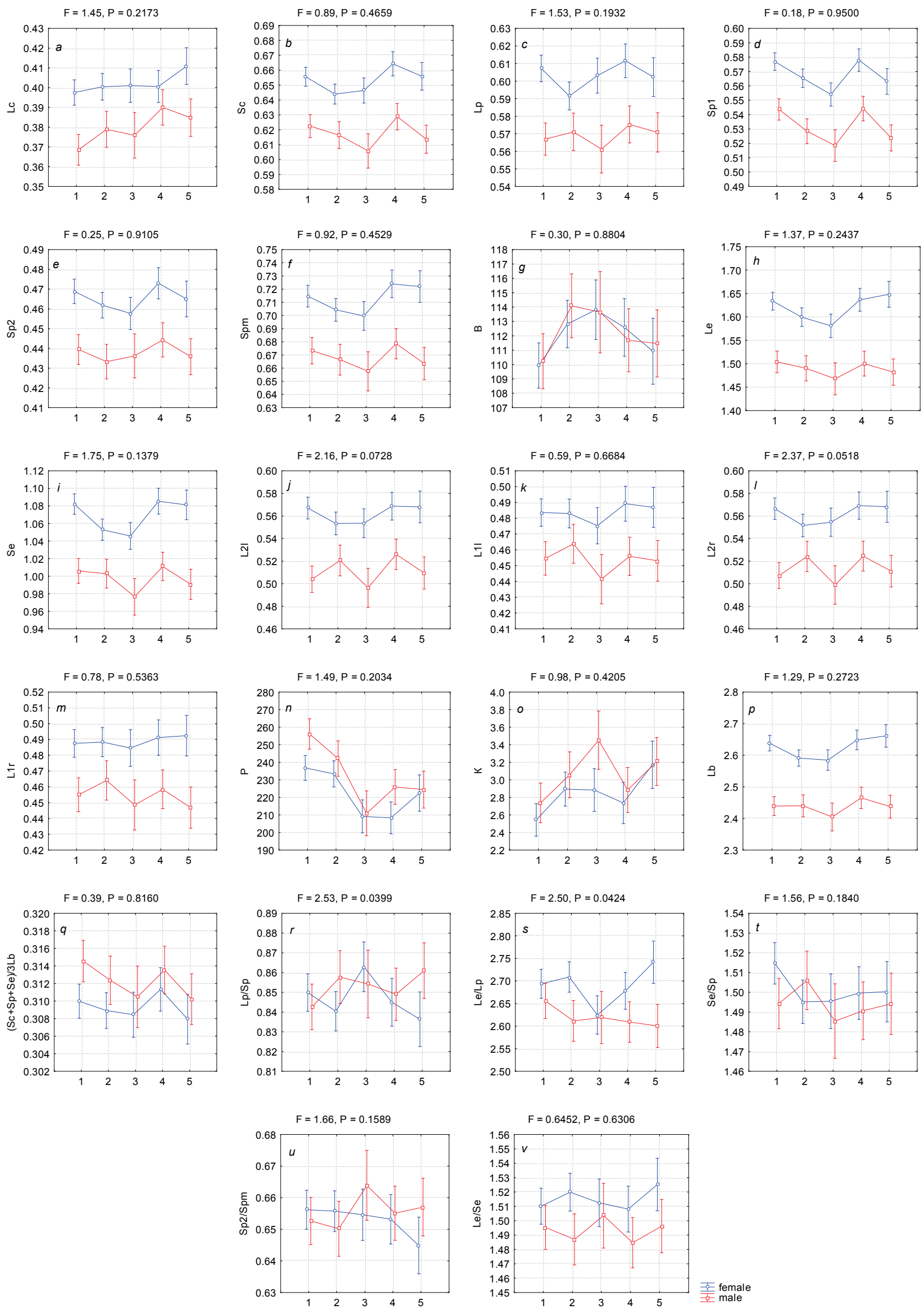

Fig. 7. Variability of morphometric characteristics of $B$. minimum body in studied populations depending on soil acidity: on $\mathrm{X}$ axis: $1-\mathrm{pH}<7.8,2-\mathrm{pH}=7.8-8.0,3-\mathrm{pH}=8.0-8.2,4-\mathrm{pH}=8.2-8.4,5-\mathrm{pH}=8.4-8.6$; notations see Table 2 

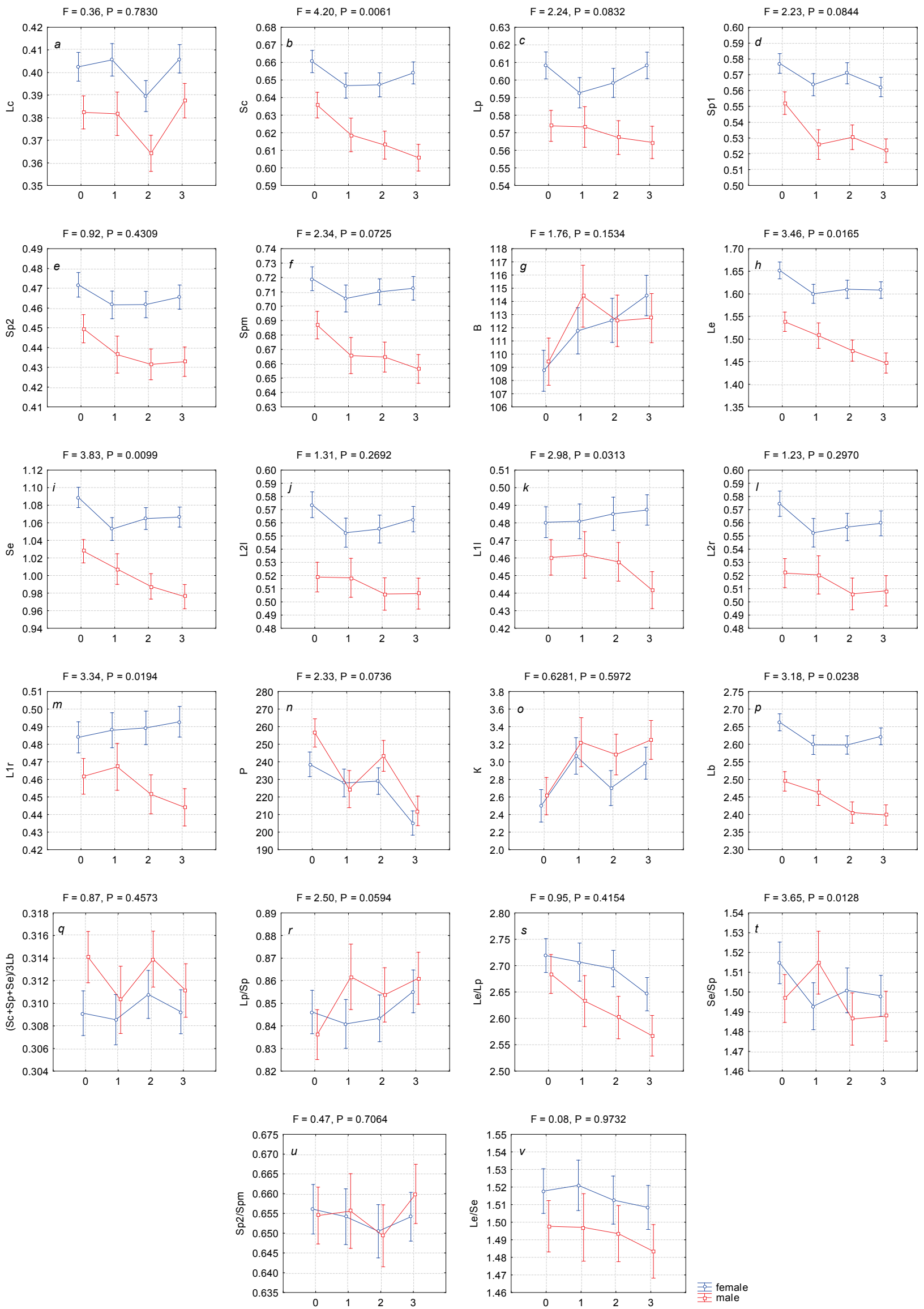

Fig. 8. Variability of morphometric characteristics of B. minimum body in studied populations depending on recreational load: on X axis - recreational load: 0 - absent (there are no human traces and household waste), 1 - slight (human traces and household waste are rare), 2 - medium (human traces and household waste occupy 10-30\% of land area), 3 - strong (human traces and household waste occupy more than $30 \%$ of land area); other notations see Table 2 

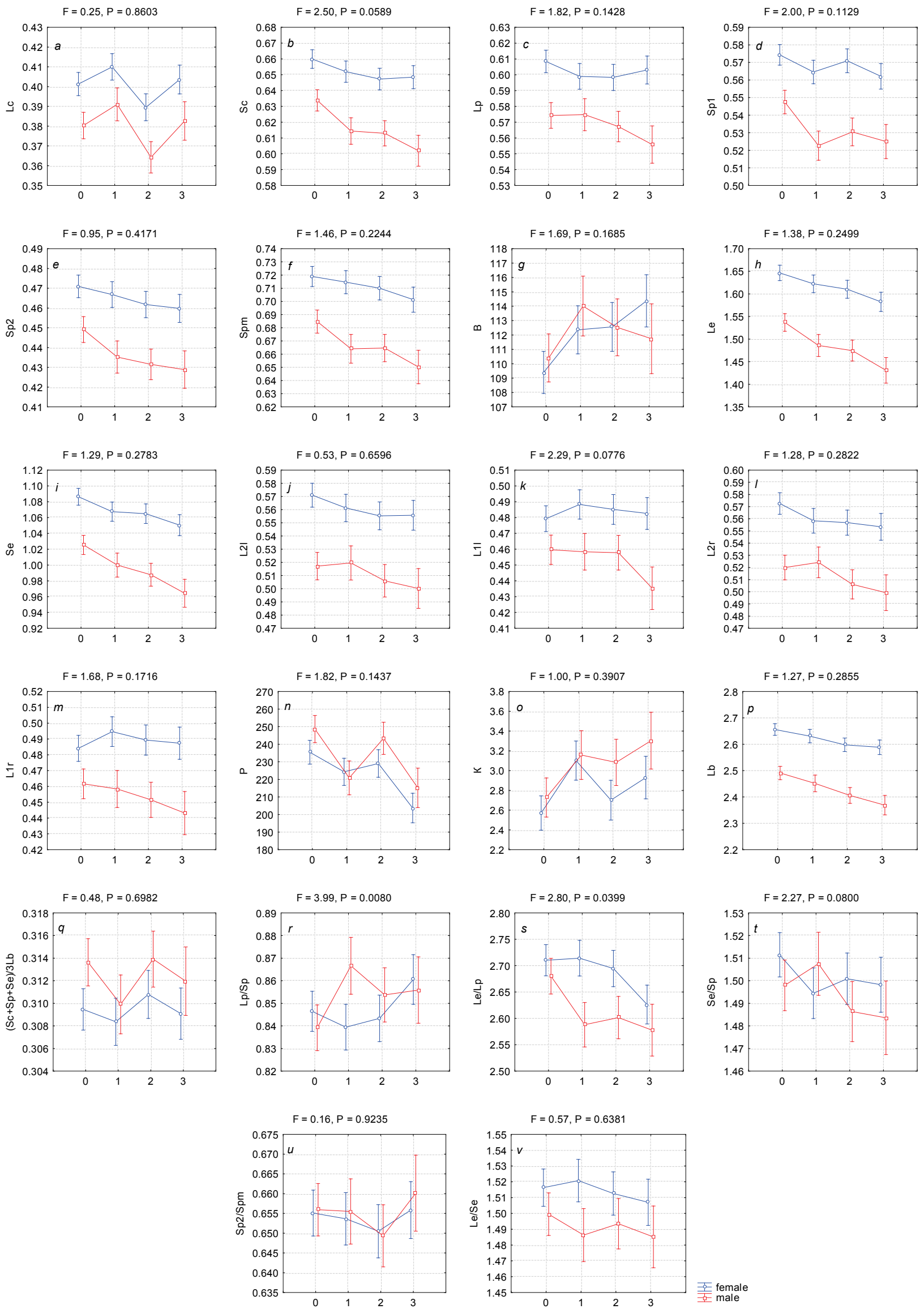

Fig. 9. Variability of morphometric characteristics of B. minimum body in studied populations depending on cattle grazing: on $\mathrm{X}$ axes -effect of cattle grazing: 0 - absent (there are no animal trails or feces), 1 - slight (animal trails and feces are rare), 2 - medium (animal trails and feces occupy $10-30 \%$ of land area), 3 - strong (animal trails and feces occupy more than $30 \%$ of land area); other notations see Table 2 

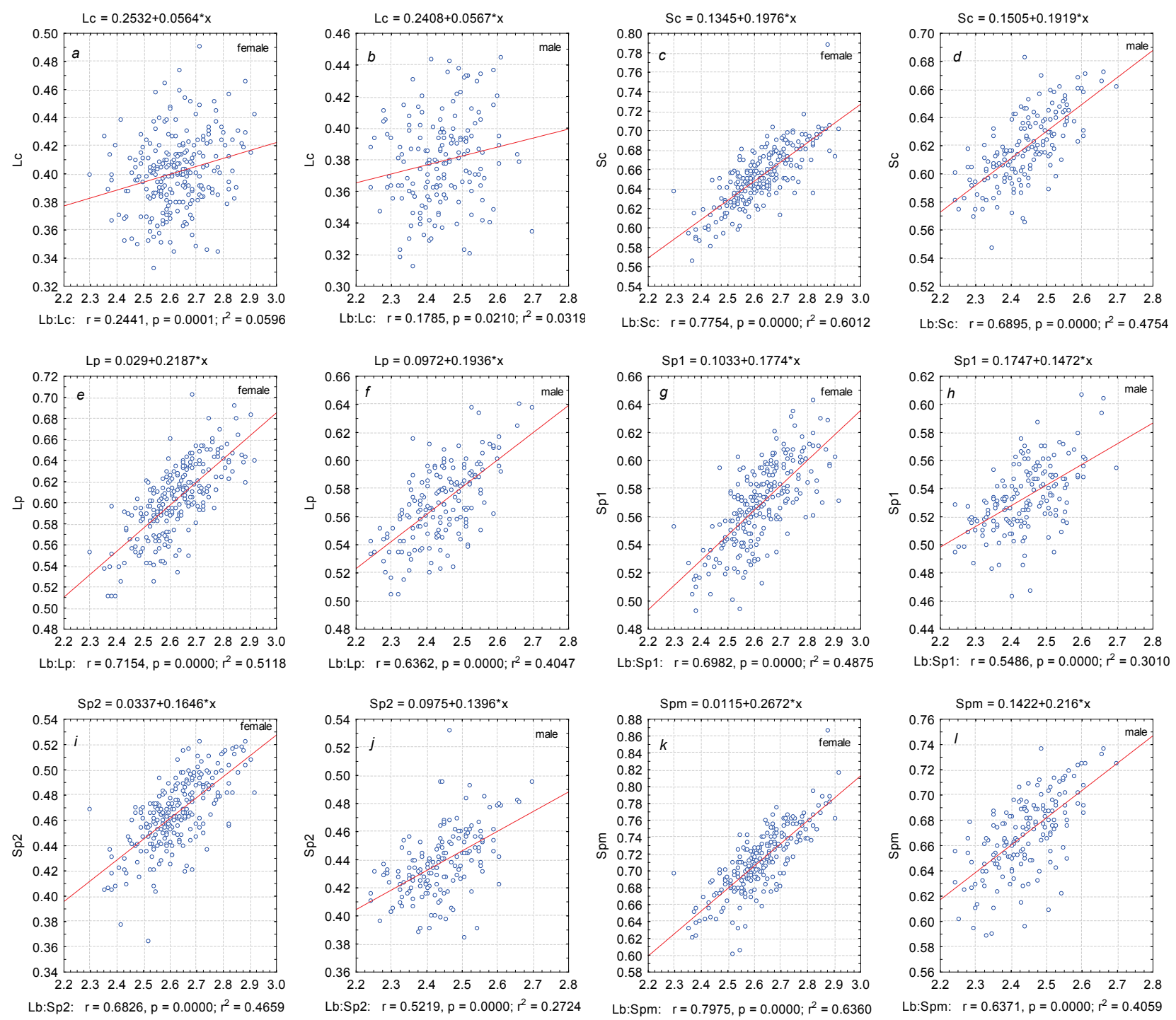

Lb:Sp2: $r=0.6826, p=0.0000 ; r^{2}=0.4659$

Lb:Sp2: $\quad r=0.5219, p=0.0000 ; r^{2}=0.2724$
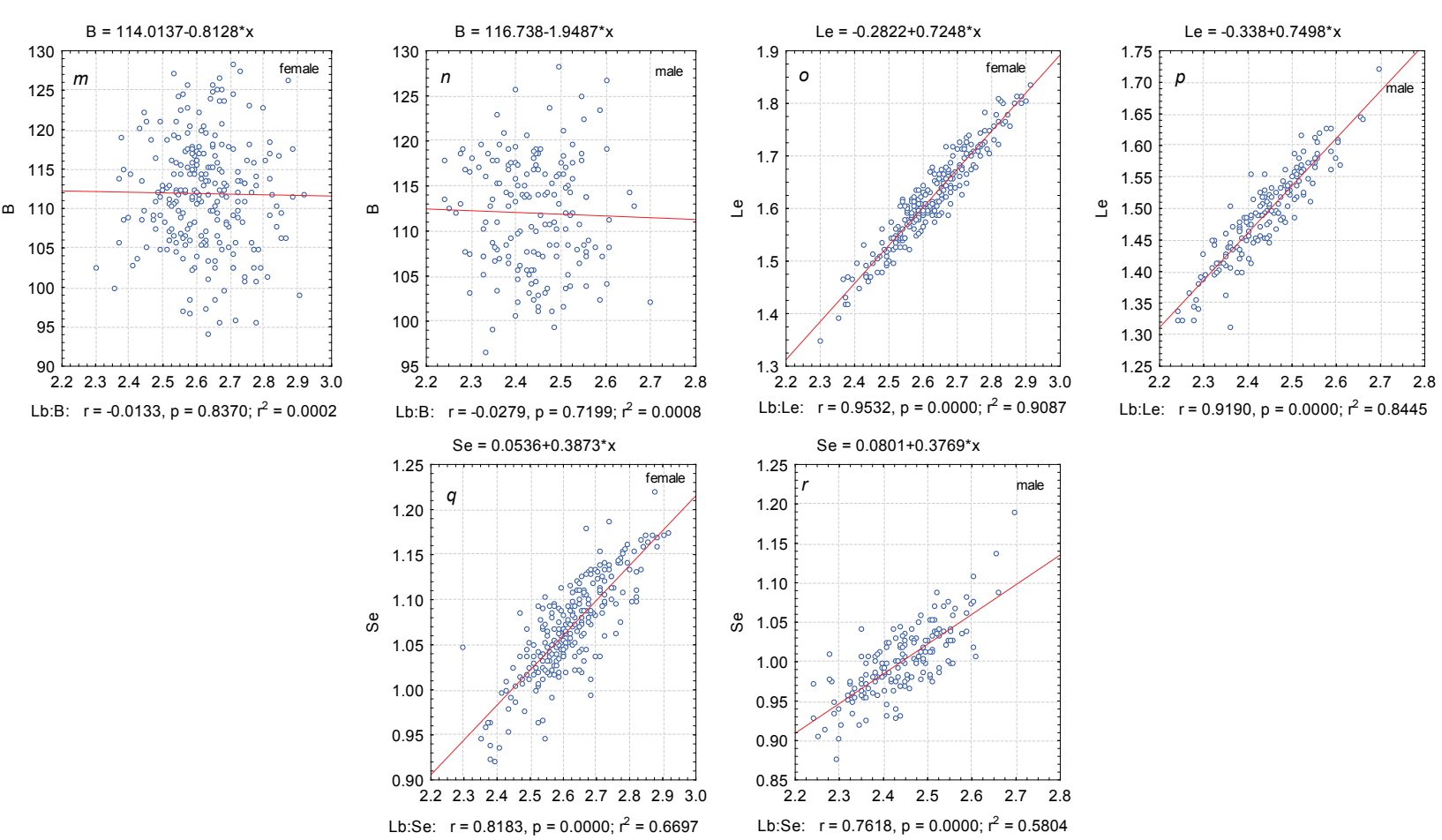

Lb:Le: $r=0.9190, p=0.0000 ; r^{2}=0.8445$

Fig. 10. Scatter diagram of linear characteristics of males and females of $B$. minimum depending on their body length: names of characteristics see Table 2 
$L 2 \mathrm{I}=0.0298+0.2028^{*} \mathrm{x}$

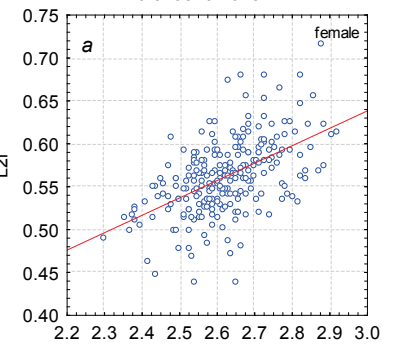

Lb:L2I: $r=0.5252, p=0.0000 ; r^{2}=0.2758$

$\mathrm{L} 2 \mathrm{r}=0.0251+0.2045^{*} x$

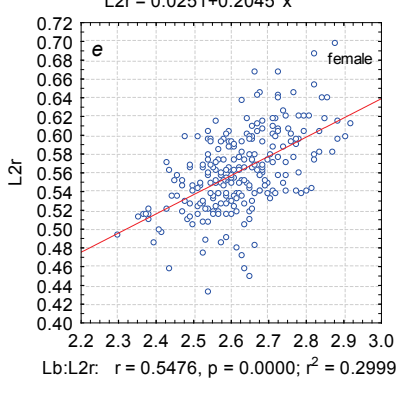

$P=338.5021-43.375^{*} x$

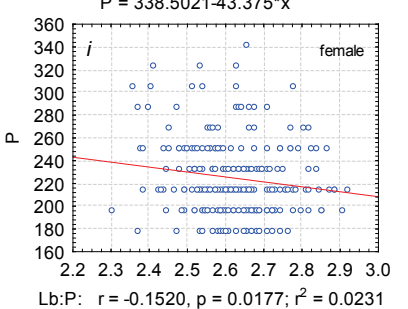

Lb:P: $r=-0.1520, p=0.0177 ; r^{2}=0.0231$

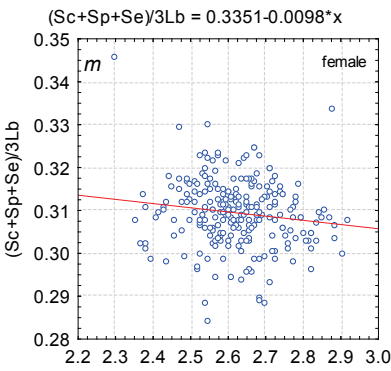

$r=-0.1393, p=0.0300 ; r^{2}=0.0194$

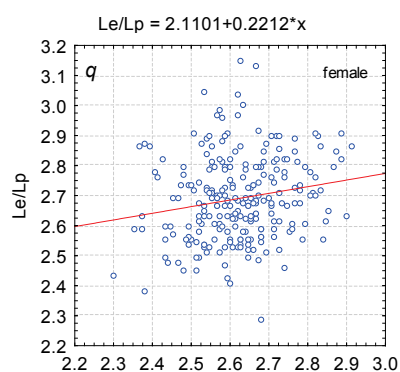

Lb:Le/Lp: $r=0.1806, p=0.0047 ; r^{2}=0.032$

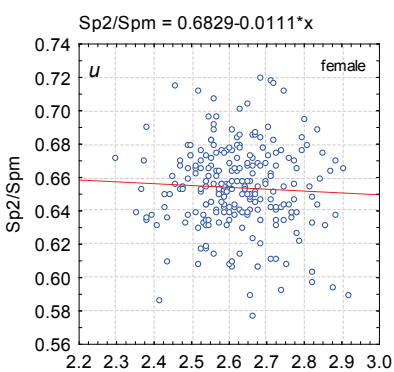

$L 21=0.0293+0.1978^{*} x$

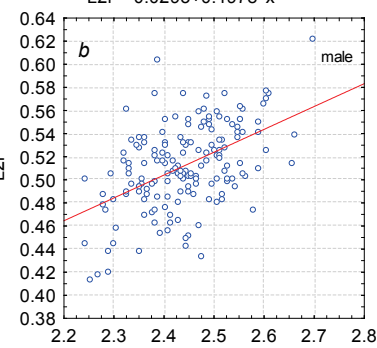

Lb:L2I: $r=0.4937, p=0.0000 ; r^{2}=0.2437$

$L 2 r=-0.0148+0.2166^{*} x$

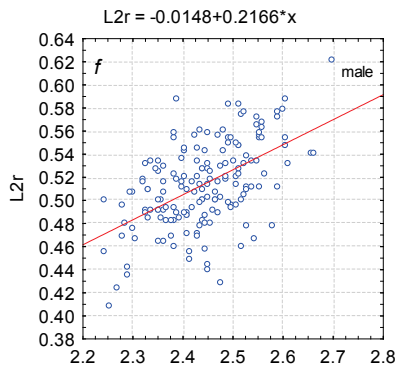

Lb:L2r: $r=0.5327, p=0.0000 ; r^{2}=0.2838$

$P=143.1224+37.8214^{*} x$

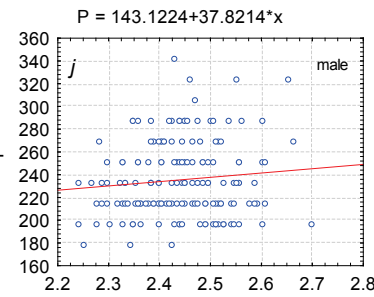

Lb:P: $r=0.1044, p=0.1792 ; r^{2}=0.0109$

$(\mathrm{Sc}+\mathrm{Sp}+\mathrm{Se}) / 3 \mathrm{Lb}=0.3648-0.0214^{*} x$

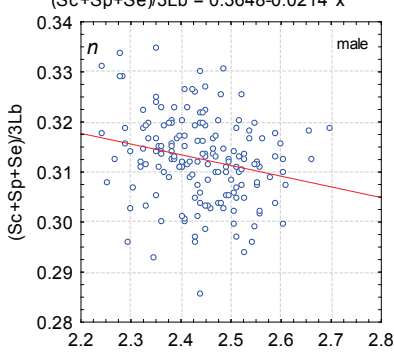

$r=-0.2267, p=0.0032 ; r^{2}=0.0514$

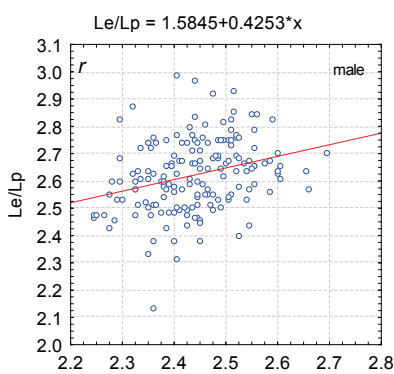

Lb:Le/Lp: $r=0.2880, p=0.0002 ; r^{2}=0.0830$

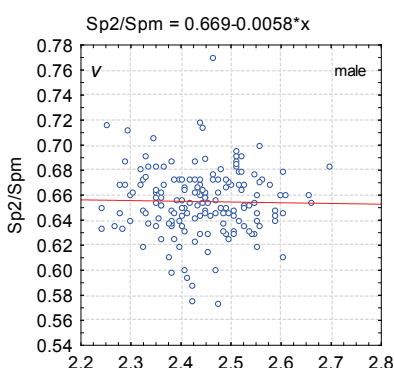

$\mathrm{L} 1 \mathrm{I}=0.1179+0.1394^{*} x$

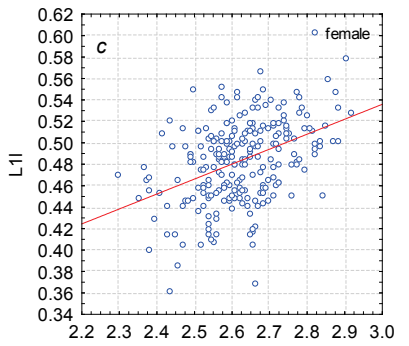

Lb:L11: $r=0.4109, p=0.0000 ; r^{2}=0.1688$

$L 1 r=0.1231+0.1393^{*} x$

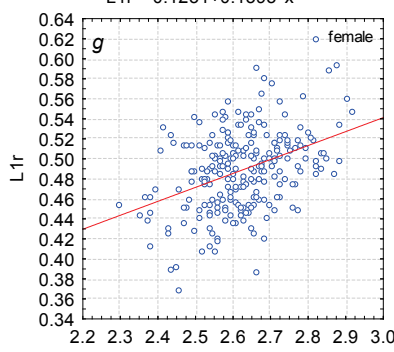

Lb:L1r: $r=0.3958, p=0.0000 ; r^{2}=0.1567$

$K=5.4228-0.9983^{*} x$

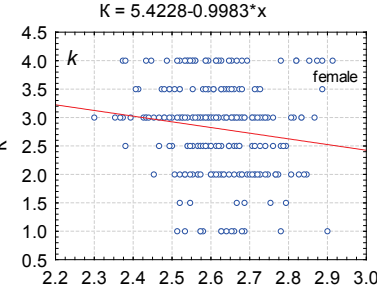

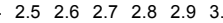

$L p / S p=0.8681-0.0081^{*} x$

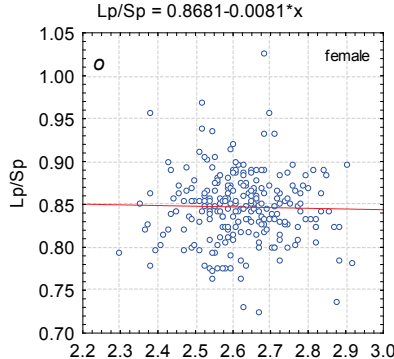

Lb:Lp/Sp: $r=-0.0227, p=0.7245 ; r^{2}=0.0005$

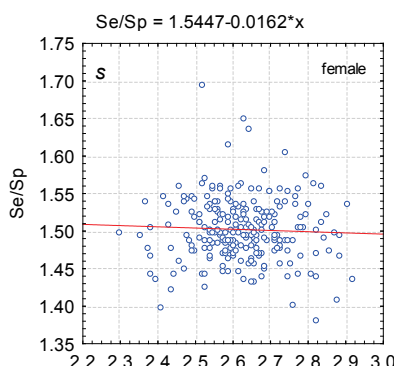

be $r=-0.0442, p=0.4924 ; r^{2}=0.0020$

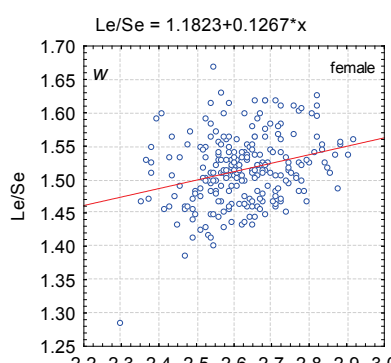

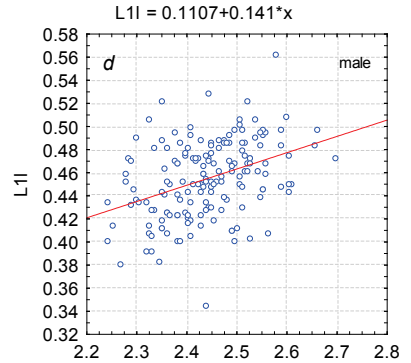

Lb:L11: $r=0.3823, p=0.00000 ; r^{2}=0.1461$

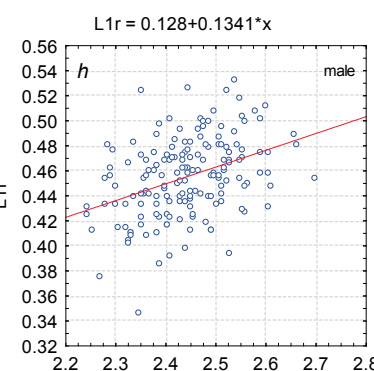

Lb:L1r: $r=0.3829, p=0.00000 ; r^{2}=0.1466$

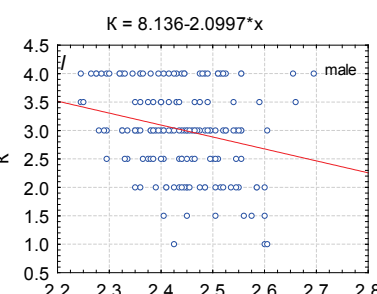

Lb:K: $r=-0.2422, p=0.0016 ; r^{2}=0.0587$

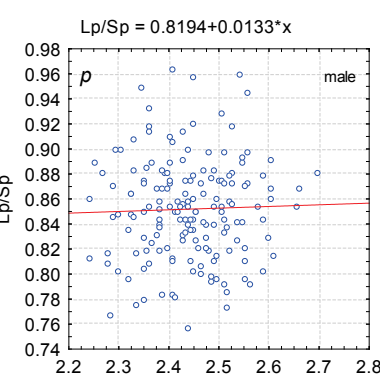

Lb:Lp/Sp: $\quad r=0.0300, p=0.7002 ; r^{2}=0.0009$

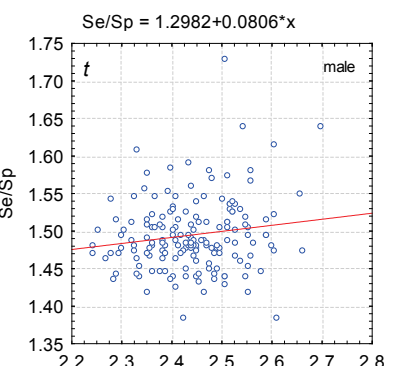

Lb:Se/Sp: $r=0.1525, p=0.0491 ; r^{2}=0.0233$

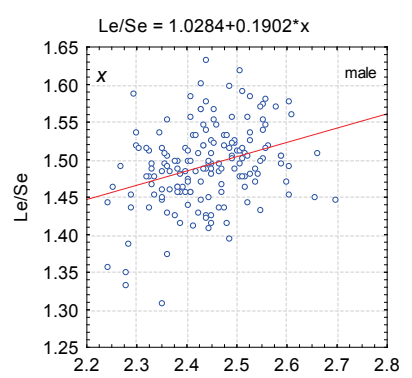

Lb:Sp2/Spm: $\quad r=-0.0498, p=0.4392 ; r^{2}=0.002$ Lb:Sp2/Spm: $r=-0.0195, p=0.8021 ; r^{2}=0.000$

Lb:Le/Se: $r=0.2782, p=0.00001 ; r^{2}=0.0774 \quad$ Lb:Le/Se: $r=0.3212, p=0.00002 ; r^{2}=0.1032$

Fig. 11. Scatter diagram of linear characteristics and indices of males and females of $B$. minimum depending on their body length: names of characteristics see Table 2 
The body length of $B$. minimum males (Lb, Fig. $8 p$ ) significantly decreases in conditions of more pronounced anthropogenic load; the ratio of maximum width of elytra to maximum prothorax width also decreases in females (Se/Sp, Fig. 8t). Significant decrease in the ratio of elytra length to prothorax length was observed in males of $B$. minimum in areas with intense anthropogenic impact (Le/Lp, Fig. 8s).

The head width (Sc, Fig. 9b), the length and width of the prothorax (Lp, Sp1, Sp2, Spm, Fig. 9c-f), the length and width of the elytra (Le, Se, Fig. $9 h, i)$ decrease in males in areas with a high degree of cattle grazing; similar but not significant changes also occur in females of this species of beetle. The value of the back angles of the prothorax (B, Fig. $9 g$ ) increases in areas with high cattle grazing in females, unlike in males. More pronounced changes under the influence of cattle grazing occur in disposition of setae in males than in females (L11, L1r, L21, L2r, Fig. 9j-m). There are significant changes in three morphometric indices: increase in the ratio of prothorax length to its maximum width in females $(\mathrm{Lp} / \mathrm{Sp}$, Fig. $9 r$ ), decrease in the ratio of elytra length to prothorax length in males and females (Le/Lp, Fig. $9 s$ ), decrease in the ratio of maximum elytra width to maximum prothorax width in males (Se/Sp, Fig. $9 t$ ) under the influence of cattle grazing.

After combination of all the measured individuals of $B$. minimum into one sample and their distribution depending on body length (Fig. 10, 11) it was found that the head length (Lc, $\mathrm{r}^{2}<0.60$, Fig. 10a, b), the value of the back angles of the prothorax $\left(\mathrm{B}, \mathrm{r}^{2}<0.001\right.$, Fig. $\left.10 m, n\right)$, the distance to the first and second setae (L11, L1r, L21, L2r, $\mathrm{r}^{2}=0.14$ 0.30 , Fig. $11 a-h)$, density of elytra puncturing $\left(\mathrm{P}, \mathrm{r}^{2}=0.01-0.02\right.$, Fig. $11 i, j)$ and the contrast of the light spots of elytra $\left(\mathrm{K}, \mathrm{r}^{2}=0.02-0.06\right.$, Fig. $11 k, l)$ are not related to body size in both females and males. None of the six studied morphometric indices also showed a relationship with the body sizes of males and females of $B$. minimum $\left(\mathrm{r}^{2}=<0.10\right.$, Fig. $11 m-x)$.

The head width $\left(\mathrm{Sc}, \mathrm{r}^{2}=0.45-0.60\right.$, Fig. $\left.10 c, d\right)$, prothorax length $\left(\mathrm{Lp}, \mathrm{r}^{2}=0.40-0.51\right.$, Fig. 10e, f), prothorax width (Sp1, Sp2, Spm, $\mathrm{r}^{2}=$ $0.27-0.64$, Fig. $10 g-l$ ), elytra width $\left(\mathrm{Se}, \mathrm{r}^{2}=0.58-0.66\right.$, Fig. $\left.10 q, r\right)$ showed average degree of connection with body size.

A strong relationship between the body sizes of males and females was found for the elytra length (Le, $\mathrm{r}^{2}=0.84-0.91$, Fig. $10 o, p$ ).

For characteristics with an average and strong degree of relationship with body size, the angle of inclination of the regression line relative to the abscissa is higher for females than for males (Fig. 10, 11).

Factor analysis of the entire array of morphometric data (Fig. 12) showed that more than a third of the variability is determined by the total body size $(\mathrm{Lb})$. Larger length and width of prothorax and elytra (Le, Se, Sc, Spm, Sp1, Sp2, Lp), longer distances to the first and second setae on the right and left elytra (L2r, L21, L1r, L11) are associated with larger body sizes. K, Lp/Sp, P correlate with smaller body sizes.

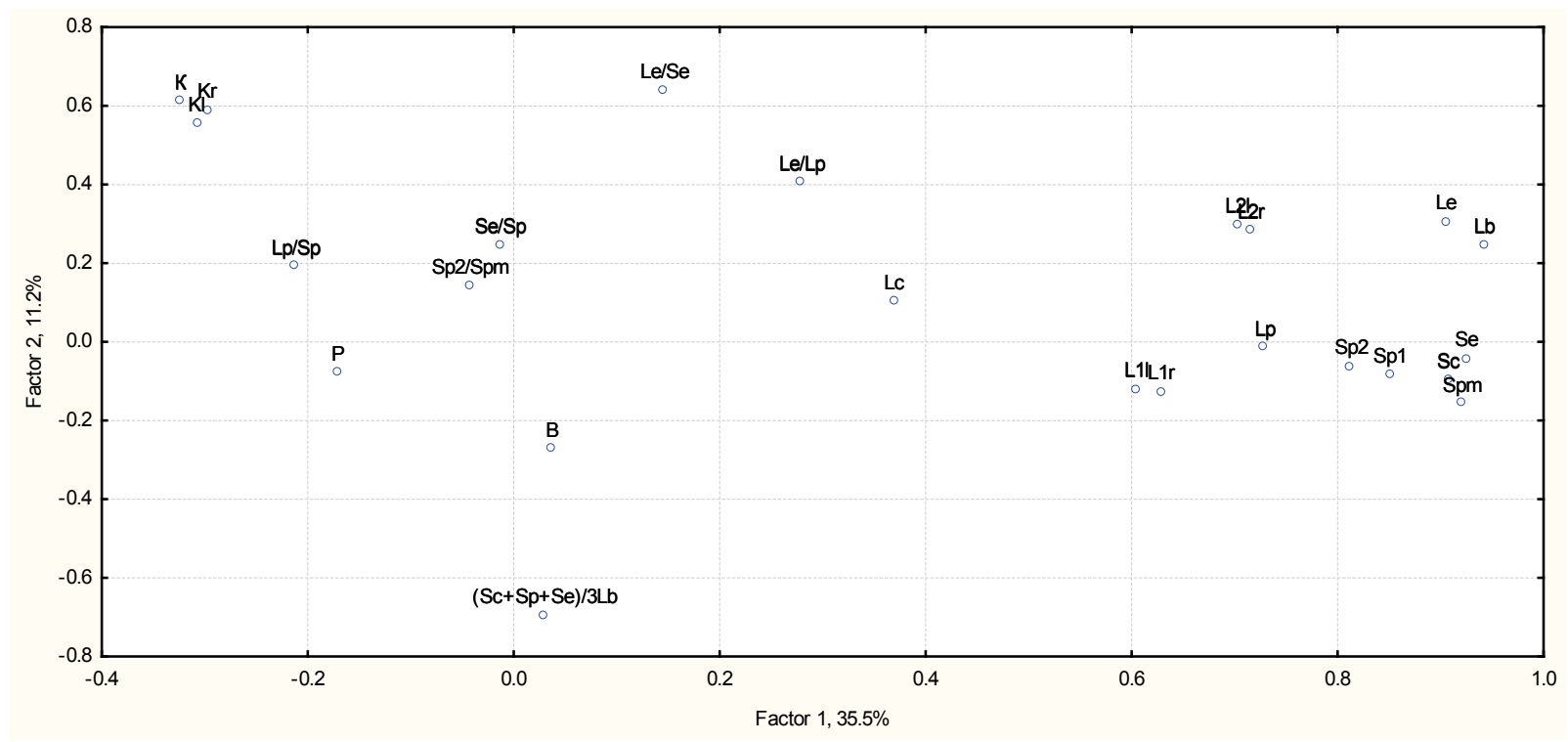

Fig. 12. Factor analysis of similarity of morphometric characteristics and indices of $B$. minimum body:

factor 1 - total body length (35.5\% of variance: positive values of factor correspond to characteristics that correlate with longer body length, negative - with shorter body length), factor 2 - body width (11.2\% of variance: positive values of factor correspond to characteristics that correlate with more "narrow" individuals, negative - with more "wide-bodied")

The second most important factor of variability (Fig. 12) is the relative body width of individuals ( $11.2 \%$ of the variance). Narrower individuals with a larger relative elytra length $(\mathrm{Le} / \mathrm{Se})$ correlate $\mathrm{K}$ and the ratio of elytra length to the prothorax length Le/Lp. Larger values of back angles of prothorax (B) are associated with larger relative body width $(\mathrm{Sc}+\mathrm{Sp}+\mathrm{Se}) / 3 \mathrm{Lb}$.

\section{Discussion}

Selye $(1976,1982)$ introduced the concept of stress and identified three stages of organism response to stress factors. The duration and nature of the course of each stage depends on many factors. The presence of stress reactions in insects, as a result of which adaptation to constantly changing environmental conditions occurs, has been proven. The morphological variability of invertebrate animals is the result of the combined effects of genes and the environment and a manifestation of adaptation (Lupi et al., 2015). The choice of habitat in insects depends on the impact of a complex of biotic and abiotic factors. The distribution of invertebrate animals in litter is determined by the influence of many fac- tors: especially the phytocenosis composition, density of the herb layer, humidity, litter thickness and mechanical structure of the soil (Faly \& Brygadyrenko, 2018). The influence of many biotic factors on ground beetles was described by Thiele back in 1977. It is difficult to assess the significance and influence of each individual factor. Brygadyrenko (2015a, b; 2016a) assessed the relationship between the forest species Badister, Calathus, Dolichus, Licinus, Panaeus (Coleoptera, Carabidae) and some environmental factors: he determined the preferences of ground beetles depending on the type of forest ecosystem, tree crown density, composition and density of the herb layer, litter thickness, humidity conditions, mechanical composition and mineralization of the soil, and the presence of ants in ecosystems. Environmental factors can affect important morphometric features of ground beetles. The variability of these features affects the ability of beetles to adapt to new environmental conditions.

There is still no consensus on at what stage of ontogenesis the influence of natural and anthropogenic environmental factors is the most significant and which of them determine and cause morphological variability of carabids. Probably, the direct and indirect influence of factors 
act most intensively at the larval stage, and are already determined at the adult stage. Change in the quantity and nature of food objects, and the diet itself takes place under the influence of environmental factors, which subsequently affects the rate of reproduction (van Dijk, 1996). The reproduction rate affects the number of eggs laid and their size. Females producing the largest number of eggs lay small eggs. Egg size in turn affects larval survival. It has been experimentally proved that large larvae from the first large eggs live longer than those from small ones (Wallin et al., 1992). The larval stage is probably the most significant in the case of the influence of environmental factors on the morphological variability of imagoes (Ernsting et al., 1992; Arndt \& Putchkov, 1997). There is a large amount of research devoted to the influence of temperature and humidity, the size of food objects (van Dijk, 1996; Ernsting \& Isaaks, 1997; Okuzaki \& Sota, 2018) at the larval stage. The effect of temperature on body length has been proven on representatives of the genus Hegeter (Tenebrionidae, Coleoptera); body width is associated with the ability of a species to dig, it is affected by rainfall, vegetation, and the amount of organic matters in the soil (De Los Santos et al., 2000). Intraspecific variability is very often explained by the biogeography of the species (influence of altitude, climate) (Koutroumpa et al., 2013; Sukhodolskaya \& Saveliev, 2016; Sukhodolskaya \& Ananina, 2017). Very little research has been devoted to other, equally important, environmental factors that can cause morphological variability of beetles.

Andersen (1985) points to the close relationship between body shape and ecological characteristics of species of the tribe Bembidiini. He confirms that dorso-ventrally complanate species with parallel elytra are adapted to live under and between stones on the banks of water bodies, and species with oval shape of the back of the body hide among vegetation, in litter and cracks in the soil; species that occupy an intermediate position between these two forms are eurybionts, and their shape does not depend on the nature of the cover. There is practically no information on the features of the ontogenesis, the description of the egg, larva, pupae for representatives of the genus Bembidion, and there is also limited information on environmental factors that can affect morphological variability at different stages of development. Several attempts have been made to study this question, monitoring the reproduction, oviposition, and development of eggs, larvae, pupae of beetles of Bembidion in laboratory and natural conditions, but have not brought positive results in most cases (Mitchell, 1963; Jensen, 1990; Theis \& Heimbach, 1994; Knapp \& Saska, 2012).

Literature data on the morphometric characteristics of B. minimum are limited to information on the total body length. The data on the body length of this species, presented in different sources, are rather uniform and vary within $2.3-3.2 \mathrm{~mm}$ (Table 10). The body length of individuals varies from 2.24 to $2.92 \mathrm{~mm}$ and in our research averages $2.55 \mathrm{~mm}$. Various authors indicate that $B$. minimum is a macropterous species (Lindroth, 1985; Hurka, 1996). All specimens collected by us also belong to the macropterous form (Matalin, 2003; Szentkiralyi et al., 2005).

Table 10

Sizes of $B$. minimum from various sources

\begin{tabular}{lcl}
\hline \multicolumn{1}{c}{ Country } & Size, $\mathrm{mm}$ & \multicolumn{1}{c}{ Source } \\
\hline Great Britain & $2.3-3.2$ & Lindroth, 1974 \\
Armenia & $2.3-2.8$ & Iablokov-Khnzorian, 1976 \\
Russia & $2.3-3.0$ & Khotko, 1978 \\
Fennoscandia, Denmark & $2.3-3.2$ & Lindroth, 1985 \\
Czech Republic, Slovakia & $2.3-3.1(2.8)$ & Hurka, 1996 \\
Tatarstan & $2.3-3.0$ & Zherebcov, 2000 \\
Ukraine & $2.24-2.92(2.55)$ & This article \\
\hline
\end{tabular}

Significant morphometric parameters for beetles are the length and relative width of the body. We found that $35.5 \%$ of $B$. minimum variability is determined by the size of the body, and the second most important factor is the relative body width of the individual. As a result of the analysis of the obtained data, it was found that head length, value of back angles of prothorax, distance to the first and second setae, contrast of light spots and density of puncturing on the elytra vary greatly within the population and are independent of body length in females and males. All morphometric indices are also independent of the population.
Diversity in elytra length is minimal. Differences in body size of ground beetles between populations are largely dependent on environmental conditions (Sukhodolskaya \& Saveliev, 2017). It is interesting that a significant effect of ecosystem factors on the linear characteristics of B. minimum was found in this research unlike with the previously studied B. articulatum (Brygadyrenko \& Slynko, 2015). The acidity and mineralization of soil are the most significant among the natural factors considered by us. They cause variability of almost all linear measurements of B. minimum individuals. Litter thickness and mechanical composition of the soil have a slight impact. The influence of anthropogenic factors (recreational load, cattle grazing) is pronounced on almost all linear parameters of imagoes.

Larger ground beetles with more massive elytra are found in areas with a more developed herb layer than in open areas (Jelaska et al., 2010; Tyler, 2010; Sukhodolskaya \& Eremeeva, 2013); for riparian species of the Cicindelidae family the reverse applies (Dangalle et al., 2013). Carabus ganulatus Linnaeus, 1758 has a more complanate body in open areas (Sukhodolskaya \& Saveliev, 2017). The type and composition of vegetation also significantly correlates with body size of ground beetles (Palmer, 1994). The effect of the herb layer on the body length of imagoes is not significant for the populations of $B$. minimum studied by us. The prothorax length, head width and prothorax width (Sp2, Spm) significantly change, although no general pattern was found for either males and females. Litter thickness is an important environmental factor that affects structure, abundance and status of the ground beetle complex (Kaizuka \& Iwasa, 2015). Increase in litter thickness is accompanied by increase in the total number of macrofauna due to the presence of saprophages in the forests of the steppe zone, the number of species increases mainly due to zoophages (Brygadyrenko, 2016b). Unexpected for us is the fact that litter thickness does not affect the linear dimensions of the body of B. minimum but causes changes in parameters such as density of puncturing and contrast of light spots on the elytra. The back spots on the elytra become brighter and acquire clear contours with thickening of the litter in females and males.

The mechanical composition of soil can affect the community of terrestrial beetles, its taxonomic structure, abundance, and morphological variability. This factor significantly affects only the total length of the body and of head of $B$. minimum.

Salinization of soil is one of the most important factors that affect the distribution of characteristics of riparian beetles. Many of them prefer saline areas, since salinization usually negatively affects the herb layer in such manner that saline areas are usually open and well lit. Salinization also inhibits the growth and contagiousness of pathogenic fungi, which is positive for beetles (Dangella et al., 2013). The level of soil mineralization affects the laying of eggs by beetles (Spomer et al., 2015), and the duration of the developmental stages and phenotypic plasticity of insects (Clark et al., 2004). Soil mineralization significantly affects body length, head length, length and width of prothorax (Sp1, $\mathrm{Sp} 2$ ) and elytra width of $B$. minimum. The results obtained in this article indicate that females of $B$. minimum are more sensitive to increased salinization of soil. The size of females of $B$. minimum increases, the length of head, prothorax, the width of prothorax between back angles and of elytra increase. However the prothorax width of females between front angles is minimal compared to females of other populations when soil mineralization is above $5 \mathrm{~g} / \mathrm{L}$.

A rather interesting question is the effect of soil acidity on ground beetles. Field and laboratory research has confirmed the presence of specific $\mathrm{pH}$ preferences in various species of ground beetles (Paje \& Mossakowski, 1984). The effect of soil acidity on the diversity of ground beetles has been proven (Sadej et al., 2012). The abundance of soil macrofauna, including ground beetles, decreases with increasing soil acidity (Kuperman, 1996). Decrease in $\mathrm{pH}$ causes decrease in the number of species of ground beetles that are resistant to humidity conditions (mesophile species), which are replaced by hygrophile taxa (Nietupski et al., 2010). Research on Popillia japonica Newman, 1838 (Coleoptera, Scarabaeidae) educed no differences in egg laying at $\mathrm{pH}$ 5.0-7.9 (Vittum \& Mozuchi, 1990). We have not found information regarding changes in the size of insects under the influence of soil $\mathrm{pH}$ in analysis of the literature data. The research presented in this article revealed the significant 
effect of soil acidity on most linear measurements of B. minimum body for both females and males. The total body length at the extreme (studied by us) $\mathrm{pH}$ values is almost the same in males and does not significantly differ in females. At $\mathrm{pH}$ 8.0-8.2 females and males of B. minimum have minimum body length, maximum prothorax width, elytra length and width.

Ground beetles have ornamental and quite diverse morphological sculptures on the surface of their elytra. The origin and significance of these sculptures is unknown. Existing theories explain the appearance of such structures as a result of sexual selection or adaptation to the environment, but they almost never result from neutral evolution (Kleisner et al., 2012). However, the absence of the influence of environmental factors on the morphological variability of the sculptures has been proved for ground beetles of the Carabus genus, their sculpture is the result of neutral evolution (Kleisner et al., 2012). Schwerk \& Jaskula (2018) educed the influence of environmental humidity during the larval stage on the number of pores on the elytra of Pterostichus oblongopunctatus (Fabricius, 1787) (Coleoptera, Carabidae). B. minimum lives in humid biotopes, therefore we considered other environmental factors that affect the variability of the number of setae per $1 \mathrm{~mm}^{2}$ of elytra surface. The most interesting fact, which requires further research, is that the number of setae significantly changes under the influence of all the factors studied by us, except for the mechanical composition of soil. This parameter does not depend on the body size of B. minimum and is greater in males than in females.

No less interesting and significant body parameters are the contrast of the light spots on the elytra and the back angles of prothorax. From the natural factors, the density of herb layer, the litter thickness and the soil acidity significantly affect the contrast of light spots on the elytra. With an increase in litter thickness the back elytra spots of $B$. minimum become pronounced with clear boundaries. We suppose that brighter colour makes it possible to be camouflaged in variably coloured litter. The density of herb layer, mineralization and acidity of the soil significantly affect the value of the back angles of the prothorax.

Morphometric indices turned out to be less informative than linear parameters for assessing the habitat of $B$. minimum. Whatever the changes in linear dimensions, the proportions of the body basically remain unchanged. We obtained similar results for $B$. articulatum (Brygadyrenko \& Slynko, 2015). Mineralization and acidity of the soil does not cause significant changes in any of six considered morphometric indexes of $B$. minimum imagoes. The density of the herb layer, in contrast, is associated with significant variability in half the morphometric indexes. The ratio of prothorax length to its maximum width is a constant for B. minimum and does not vary under the influence of the considered natural and anthropogenic factors.

Human activity leads to change in landscapes, affects biodiversity and structure of natural ecosystems. The area of disturbed territories is increasing every year (Sukhodolskaya, 2013). This causes change in soil and vegetation layer, and structure of animal populations. Habitat quality affects the size and weight of ground beetles (den Nijs et al., 1996). The impact of anthropogenic factors on the ground beetle complex can be successfully determined using morphometric methods (Benitez et al., 2018). It is recommended to use body size and other morphological features of beetles to assess impact of human activity on the environment.

The size of the body of some species of ground beetles decreases in urban habitats (Weller \& Ganzhorn, 2004; Sukhodolskaya, 2013). Researchers have also identified the effects of heavy metal pollution: zinc, lead, cadmium on the morphometric features of ground beetles (Lagisz, 2008; Osman et al., 2015; Sowa \& Skalski, 2019). Females from polluted zones are smaller than females from the control populations. No definite pattern of morphometric parameters was revealed for males of different species: in some the changes concerned only the prothorax, in others - only the elytra, in the third - both of them (Sowa \& Skalski, 2019). Different morphometric parameters of individual species vary differently in the gradient of the same anthropogenic factor (Sukhodolskaya \& Saveliev, 2014). Head width, elytra length and four morphometric indices significantly change in $B$. aspericolle under the influence of anthropogenic factors (Komlyk \& Brygadyrenko, 2019). Changes in the linear dimensions of $B$. minimum body with an increase in recrea- tional load and cattle grazing are similar to those found in our researches. Significant influence of the recreational load on all linear parameters of the body of individuals was observed for the total sample of $B$. minimum except for prothorax length and distance from the base of the elytra to the first setae, and two of the six indices. $B$. minimum is characterized by decrease in body length, length and width of the elytra, width of prothorax between back angles, maximum width of prothorax, ratio of elytra length to prothorax length for both females and males with increase in recreational load. Smaller body size may indicate a low adaptability of this species to recreational load.

The body size of different species of ground beetles decreases in the gradient of intensification of agricultural activity including cattle grazing (Burel et al., 2004). Cattle grazing and trampling is one of the priority factors in the destruction of shore ecosystems in the steppe zone of Ukraine. Almost all linear characteristics of B. minimum and three of the six indices of body proportions significantly change under the influence of cattle grazing. Body length, head width, length and width of prothorax, length and width of elytra decrease both in females and males in areas with high degree of cattle grazing.

Expected for us was the dependence of length and width of elytra, length and width of prothorax on body length of $B$. minimum. Deviation from the average values of these characteristics is greater in males than in females. The head length is not related to the total body size in females and males. The fact that the distances from the base of the elytra to the first setae, and the distance between setae of both females and males are independent of their body length is interesting and requires further research on other species of ground beetles. The first and second elytra setae are used to measure the distance between dorsal surface of the imago body and walls of the soil crack in which the beetle is located. The beetle remains in an excited state until all four setae on the elytra are bent to the elytra signaling to the central nervous system that the insect is safe. Probably these setae can also perceive sound vibrations of air. We expected that the distance from the base of elytra to setae would increase with body length of beetle, i.e. that isometric variability would be observed. This was not observed.

The most discernible sexual dimorphism is in evidence for beetles especially for ground beetles (Alibert et al., 2001; Kawano, 2006; Bravi \& Benitez, 2013). Intraspecific sexual dimorphism is a stable value. Females are larger than males in most ground beetle species (Sota et al., 2000; Sukhodolskaya \& Saveliev, 2017). Ground beetles can be divided into two groups: in some - females are more sensitive to environmental changes, in others - males. In our researches, $B$. minimum females are larger than males, as with $B$. articulatum and $B$. aspericolle (Brygadyrenko \& Slynko, 2015; Komlyk \& Brygadyrenko, 2019). Sexual dimorphism of B. minimum is in evidence in all linear parameters and most morphometric indices. Sexual dimorphism does not appear in value of back angles of the prothorax or in the ratio of maximum width of prothorax to its width between back angles. We can say that there are no differences between females and males in the form of the prothorax.

\section{Conclusions}

Despite the availability of research on morphological variability of ground beetles, the features of influence of environmental factors on each stage of ontogenesis are still not disclosed. It is not clear at what stages of development the influence of environmental factors is most significant and which factors mainly determine and cause morphological variability of ground beetles. The dependence shown in this article of variability of linear parameters and morphometric indices of B. minimum on natural and anthropogenic factors suggests the need for further research on this issue at the population level. The study of morphological variability will help to identify causes and mechanisms of ground beetle adaptation to existence in natural and anthropogenically transformed ecosystems.

\section{References}

Abdel-Dayem, M. S. (1998). The Egyptian species of Bembidion Latreille, 1802 (Coleoptera, Carabidae). Bulletin of the Entomological Society of Egypt, 76, 181-198. 
Alibert, P., Moureau, B., Dommergues, J. L., \& David, B. (2001). Differentiation at a microgeographical scale within two species of ground beetle, Carabus auronitens and C. nemoralis (Coleoptera, Carabidae): A geometrical morphometric approach. Zoologica Scripta, 30(4), 299-311.

Andersen, L. (1985). Ecomorphological adaptations of riparian Bembidiini species (Coleoptera: Carabidae). Entomologia Generalis, 11(1-2), 41-46.

Arndt, E., \& Putchkov, A. V. (1997). Phylogenetic investigation of Cicindelidae (Insecta: Coleoptera) using larval morphological characters. Zoologischer Anzeiger, 234(3-4), 231-241.

Band, E. (1892). Familienreihe Caraboidea. Wien, Druck und Verlag von Carl Gerold's Sohn.

Barton, P. S., Gibbk, H., Manningk, A., Lindenmayer, D. B., \& Cunningham, S. A. (2011). Morphological traits as predictors of diet and microhabitat use in a diverse beetle assemblage. Biological Journal of the Linnean Societ, 102(2), 301-310.

Benitez, H. A., Lemic, D., Puschel, T. A., Gasparic, H. V., Kos, T., Baric, B., Bazok, R., \& Zivkovic, I. P. (2018). Fluctuating asymmetry indicates levels of disturbance between agricultural productions: An example in Croatian population of Pterostichus melas melas (Coleptera: Carabidae). Zoologischer Anzeiger, 276, 42-49.

Bravi, R., \& Benitez, H. A. (2013). Left-right asymmetries and shape analysis on Ceroglossus chilensis (Coleoptera: Carabidae). Acta Oecologica, 52, 57-62.

Brygadyrenko, V. V. (2015a). Evaluation of the ecological niche of some abundant species of the subfamily Platyninae (Coleoptera, Carabidae) against the background of eight ecological factors. Folia Oecologica, 42(2), 75-88.

Brygadyrenko, V. V. (2015b). Parameters of ecological niches of Badister, Licinus and Panagaeus (Coleoptera, Carabidae) species measured against eight ecological factors. Baltic Journal of Coleopterology, 15(2), 137-154.

Brygadyrenko, V. V. (2016a). Evaluation of ecological niches of abundant species of Poecilus and Pterostichus (Coleoptera: Carabidae) in forests of the steppe zone of Ukraine. Entomologica Fennica, 27(2), 81-100.

Brygadyrenko, V. V. (2016b). Influence of litter thickness on the structure of litter macrofauna of deciduous forests of Ukraine's steppe zone. Visnyk of Dnipropetrovsk University. Biology, Ecology, 24(1), 240-248.

Brygadyrenko, V. V., \& Fedorchenko, D. O. (2008). Morfologichna minlyvist' populjacii' Carabus hungaricus scythes (Coleoptera, Carabidae) v umovah ostrova Hortycja (Zaporiz'ka oblast') [Morphological variability of populations Carabus hungaricus scythus (Coleoptera, Carabidae) on Khortitsa Island (Zaporizhzhya province)]. Visnyk of Dnipropetrovsk University, Biology, Ecology, 16(1), 20-27.

Brygadyrenko, V. V., \& Reshetniak, D. Y. (2016). Morphometric variability of Clitellocephalus ophoni (Eugregarinida, Gregarinidae) in the intestines of Harpalus rufipes (Coleoptera, Carabidae). Archives of Biological Sciences, 68(3), 587-601.

Brygadyrenko, V. V., \& Slynko, V. O. (2015). Morphological variability of Bembidion articulatum (Coleoptera, Carabidae) populations: Linear dimensions depend on sex, while morphological indices depend on ecosystems. International Journal of Applied Environmental Sciences, 10, 163-187.

Burel, F., Butet, A., Delettre, Y. R., \& de la Pena, N. M. (2004). Differential response of selected taxa to landscape context and agricultural intensification. Landscape and Urban Planning, 67(1-4), 195-204.

Clark, T. M., Flis, B. J., \& Remold, S. K. (2004). Differences in the effects of salinity on larval growth and developmental programs of a freshwater and a euryhaline mosquito species (Insecta: Diptera, Culicidae). Journal of Experimental Biology, 207, 2289-2295.

Dangalle, C. D., Pallewatta, N., \& Vogler, A. P. (2013). The association between body-size and habitat-type in tiger beetles (Coleoptera, Cicindelidae) of Sri Lanka. Ceylon Journal of Science (Biological Sciences), 42(1), 41-53.

De Los Santos, A., Gomez-Gonzalez, L. A., Alonso, C., Arbelo, C. D., \& De Nicolas, J. P. (2000). Adaptive trends of darkling beetles (Col. Tenebrionidae) on environmental gradients on the island of Tenerife (Canary Islands). Journal of Arid Environments, 45(1), 85-98.

denNijs, L. J. M. F., Lock, C. A. M, Noorlander, J., \& Booij, C. J. H. (1996). Search for quality parameters to estimate the condition of Pterostichus cupreus (Col., Carabidae) in view of population dynamic modeling. Journal of Applied Entomology, 120(3), 147-151.

Desender, K., \& Maelfait, J.-P. (1999). Diversity and conservation of terrestrial arthropods in tidal marshes along the river Schelde: A gradient analysis. Biological Conservation, 87, 221-229.

Desender, K., \& Verdyck, P. (2001). Geographic scaling and genetic differentiation in two highly mobile European saltmarsh beetles. Belgian Journal of Zoology, 131(1), 31-42.

Di Grumo, D., \& Lovei, G. (2016). Body size inequality in ground beetle (Coleoptera: Carabidae) assemblages as a potential method to monitor environmental impacts of transgenic crops. Periodicum Biologorum, 118(3), 223-230.

Emsting, G., \& Isaaks, J. A. (1997). Effects of temperature and season on egg size, hatchling size and adult size in Notiophilus biguttatus. Ecological Entomology, 22(1), 32-40.
Ernsting, G., Isaaks, J. A., \& Berg, M. P. (1992). Life-cycle and food availability indexes in Notiophilus biguttatus (Coleoptera, Carabidae). Ecological Entomology, 17(1), 33-42.

Erwin, T. L. (1979). A review of the natural history and evolution of ectoparasitoid relationships in Carabid beetles. In: Erwin, T. L., Ball, G. E., Whitehead, D. R., \& Halpern, A. L. (Eds.). Carabid beetles, their evolution, natural history, and classification. Proc. 1st Int. Symp. Carabidology. Dr. W. Junk, The Hague. Pp. 479-484.

Eyre, M. D., \& Luff, M. L. (2004). Ground beetle species (Coleoptera, Carabidae) associations with land cover variables in northern England and Southern Scotland. Ecography, 27(4), 417-426.

Faly, L. I., \& Brygadyrenko, V. V. (2018). Influence of the herbaceous layer and litter depth on the spatial distribution of litter macrofauna in a forest plantation. Biosystems Diversity, 26(1), 46-51.

Georges, A., Fouillet, P., \& Petillon, J. (2011). Changes in salt-marsh carabid assemblages after an invasion by the native grass Elymus athericus (Link) Kerguelen. Zookeys, 100, 407-419.

Gobbi, M., \& Fontaneto, D. (2008). Biodiversity of ground beetles (Coleoptera: Carabidae) in different habitats of the Italian Po lowland. Agriculture Ecosystems and Environment, 127(3-4), 273-276.

Hieke, F., \& Wrase, W. (1988). Faunistik der laufkafer Bulgariens (Coleotera, Carabidae). Deutsche Entomologische Zeitschrift, 35 (1-3), 1-171.

Hurka, K. (1996). Carabidae of the Czech and Slovak Republics. Kabourek, Zlin.

Iablokov-Khnzorian, S. M. (1976). Fauna Armyanskoy SSR. Zhuzhelicy (Carabidae). Ch. 1. [Fauna of the Armenian Republic of the USSR. Ground beetles (Carabidae)]. Izdatelstvo AN Armyanskoy SSR, Erevan (in Russian).

Irmler, U., Heller, K., Meyer, H., \& Reinke, H.-D. (2002). Zonation of ground beetles (Coleoptera: Carabidae) and spiders (Araneida) in salt marshes at the North and the Baltic Sea and the impact of the predicted sea level increase. Biodiversity and Conservation, 11(7), 1129-1147.

Jelaska, L. S., Jesovnik, A., Jelaska, S. D., Pirnat, A., Kucinic, M., \& Durbesic, P. (2010). Variations of carabid beetle and ant assemblages, and their morphoecological traits within natural temperate forests in Medvednica Nature Park. Sumarski List, 134, 475-486.

Jensen, L. B. (1990). Effect of temperature on the development of the immature stages of Bembidion lampros (Coleoptera: Carabidae). Entomophaga, 35(2), 277-281.

Johnson, W. F., \& Halbert, J. N. (1902). A list of the beetles of Ireland. Proceedings of the Royal Irish Academy, 6, 535-827.

Kaizuka, J., \& Iwasa, M. (2015). Carabid beetles (Coleoptera: Carabidae) in coniferous plantations in Hokkaido, Japan: Effects of tree species and environmental factors. Entomological Science, 18(2), 245-253.

Kamer, N., Dormann, W., \& Mossakowski, D. (2008). Patterns of molecular variability in Carabid beetles mostly from the Baltic Sea coast. In: Pennev, L., Erwin, T., \& Assmann, T. (Eds.). Back to the roots and back to the future. Towards a new synthesis amongst taxonomic, ecological and biogeographical approaches in carabidology. XIII European Carabidologists Meeting, Blagoevgrad (Bulgaria), August 2007. Pensoft Publishers, Sofia-Moscow. Pp. 195-206.

Kawano, K. (2006). Sexual dimorphism and the making of oversized male characters in beetles (Coleoptera). Annals of the Entomological Society of America, 99(2), 327-341.

Khotko, E. I. (1978). Opredelitel zhuzhelits (Coleoptera, Carabidae) [Key to ground beetles (Coleoptera, Carabidae)]. Nauka i Tekhnika, Minsk (in Russian).

Kikoti, I. A., \& Mligo, C. (2015). Impacts of livestock grazing on plant species composition in montane forests on the northern slope of Mount Kilimanjaro, Tanzania. International Journal of Biodiversity Science, Ecosystem Services and Management, 11(2), 114-127.

Kleisner, K., Keil, P., \& Jaros, F. (2012). Biogeography of elytral ornaments in Palearctic genus Carabus: Disentangling the effects of space, evolution and environment at a continental scale. Evolutionary Ecology, 26(4), 1025-1040.

Knapp, M., \& Saska, P. (2012). The effects of habitat, density, gender and duration on overwintering success in Bembidion lampros (Coleoptera: Carabidae). Journal of Applied Entomology, 136(3), 225-233.

Komlyk, V. O., \& Brygadyrenko, V. V. (2019). Morphological variability of Bem bidion aspericolle (Coleoptera, Carabidae) populations in conditions of anthropogenic impact. Biosystems Diversity, 27(1), 21-25.

Koutroumpa, F. A., Rougon, D., Bertheau, C., Lieutier, F., \& Roux-Morabito, G. (2013). Evolutionary relationships within European Monochamus (Coleoptera: Cerambycidae) highlight the role of altitude in species delineation. Biological Journal of the Linnean Society, 109(2), 354-376.

Kryzhanovskij, O. L., Belousov, I. A., Kabak, I. I., Kataev, B. M., Makarov, K. V., \& Shilenkov, V. G. (1995). A checklist of the ground-beetles of Russia and Adjacent Lands. Pensoft, Sofia-Moscow.

Kuperman, R. G. (1996). Relationships between soil properties and community structure of soil macroinvertebrates in oak-hickory forests along an acidic deposition gradient. Applied Soil Ecology, 4(2), 125-137. 
Lagisz, M. (2008). Changes in morphology of the ground beetle Pterostichus oblongopunctatus F. (Coleoptera; Carabidae) from vicinities of a zinc and lead smelter. Environmental Toxicology and Chemistry, 27(8), 1744-1747.

Lindroth, C. H. (1974). Coleoptera, Carabidae. Handbooks for the identification of British insects. Royal Entomological Society of London, London.

Lindroth, C. H. (1985) The Carabidae (Coleoptera) of Fennoscandia and Denmark. Fauna Entomologica Scandinavica, 15(1), 1-226.

Luff, M. L. (1998). Provisional atlas of the ground beetles (Coleoptera, Carabidae) of Britain. Biological Records Centre, Huntingdon.

Lupi, D., Jucker, C., Rocco, A., Harrison, R., \& Colombo, M. (2015). Notes on biometric variability in invasive species: The case of Psacothea hilaris hilaris. Bulletin of Insectology, 68(1), 135-145.

Matalin, A. V. (2003). Variations in flight ability with sex and age in ground beetles (Coleoptera, Carabidae) of South-Western Moldova. Pedobiologia 47(4), 311-319.

Meijer, J. (1974). A comparative study of the immigration of carabids (Coleoptera, Carabidae) into a new polder. Oecologia, 16(3), 185-208.

Mitchell, B. (1963). Ecology of two carabid beetles, Bembidion lampros (Herbst) and Trechus quadristriatus (Schrank). Journal of Animal Ecology, 32(2), 289-299.

Moskalev, A., Zhikrivetskaya, S., Krasnov, G., Shaposhnikov, M., Proshkina, E. Borisoglebsky, D., Danilov, A., Peregudova, D., Sharapova, I., Dobrovolskaya, E., Solovev, I., Zemskaya, N., Shilova, L., Snezhkina, A., \& Kudryavtseva, A. (2015). A comparison of the transcriptome of Drosophila melanogaster in response to entomopathogenic fungus, ionizing, starvation and cold shock. BMC Genomics, 16(13), S8.

Muhar, A., Arnberger, A., \& Brandenburg, C. (2002). Methods for visitor monitoring in recreational and protected areas: An overview. In: Monitoring and management of visitor flows in recreational and protected areas. Conference Proceedings. Pp. 1-6.

Nietupski, M., Sowinski, P., Sadej, W., \& Kosewska, A. (2010). Content of organic $\mathrm{C}$ and $\mathrm{pH}$ of bog and post-bog soils versus the presence of ground beetles Carabidae in Stary Dwor near Olsztyn. Journal of Elementology, 15(3), 581-591.

Nitzu, E. (2003). Contributions to the knowledge of the tribus Bembidiini (Coleoptera: Carabidae) from Romania. Travaux du Muséum National d'Histoire Naturelle "Grigore Antipa", 45, 179-185.

Okuzaki, Y., \& Sota, T. (2018). Predator size divergence depends on community context. Ecology Letters, 21(7), 1097-1107.

Osman, W., El-Samad, L. M., Mokhamer, E. H., El-Touhamy, A., Shonouda, M. (2015). Ecological, morphological, and histological studies on Blaps polycresta (Coleoptera: Tenebrionidae) as biomonitors of cadmium soil pollution. Environmental Science and Pollution Research, 22(18), 14104-14115.

Paje, F., \& Mossakowski, D. (1984). pH-preferences and habitat selection in carabid beetles. Oecologia, 64(1), 41-46.

Palmer, M. (1994). Ecological factors associated with body-size in populations of Macrothorax morbillosus (F.) (Carabidae, Coleoptera). Acta Oecologica, 15(6), 689-699.

Putchkov, A. V. (2011). Ground beetles of the Ukraine (Coleoptera, Carabidae) ZooKeys, 100, 503-515.

Putchkov, A. V. (2012). Faunisticheskiy obzor karaboidnyh zhukov (Coleoptera, Caraboidea) Ukrainy [A review of the caraboids-beetles (Coleoptera, Caraboidea) of Ukraine]. Ukrayinskiy Entomologichniy Zhurnal, 2(5), 3-44 (in Russian)

Petillon, J., Georges, A., Canard, A., \& Ysnel, F. (2007). Impact of cutting and sheep grazing on ground-active spiders and carabids in intertidal salt marshes (Western France). Animal Biodiversity and Conservation, 30(2), 201-209.

Rozek, M., \& Rudek, Z. (1992). Karyotype analysis and c-banding pattern in 2 species of carabid (Coleoptera, Carabidae). Folia Biologica, 40(1-2), 47-52.

Sadej, W., Kosewska, A., Sadej, W., \& Nietupski, M. (2012). Effects of fertilizer and land-use type on soil properties and ground beetle communities. Bulletin of Insectology, 65(2), 239-246.

Schultz, R. (2000). Ground beetles (Coleoptera: Carabidae) as indicators for the efficiency of the revitalization of salt grassland at the Baltic Sea coast. Mitteilungen der Deutschen Gesellschaft fuer Allgemeine und Angewandte Entomologie, 12, 389-394.

Schwerk, A., \& Jaskula, R. (2018). Rare patterns of dorsal puncture in Pterostichus oblongopunctatus (Coleoptera: Carabidae). PeerJ, 6, e4657.

Selye, H. (1976). Stress without distress. In: Serban, G. (Ed.). Psychopathology of human adaptation. Springer, Boston. Pp. 137-146.

Selye, H. (1982). Stress bez distressa [Stress without distress]. Progress, Moscow (in Russian)
Slinko, V. O., Brygadyrenko, V. V., \& Pakhomov, O. Y. (2008). Morfologicheskaja izmenchivost' Bembidion varium (Carabidae, Coleoptera) v uslovijah antropogennogo vozdejstvija [Morphological variability of Bembidion varium (Carabidae, Coleoptera) in the conditions of anthropogenic pressure]. Proceedings of the National Academy of Sciences of Azerbaijan (Biological Sciences), 64(5-6), 200-206 (in Russian).

Sota, T., Takami, Y., Kubota, K., Ujiie, M., \& Ishikawa, R. (2000). Intraspecific body size differentiation in species assemblages of the carabid subgenus Ohomopterus in Japan. Population Ecology, 42, 279-291.

Sowa, G., \& Skalski, T. (2019). Effects of chronic metal exposure on the morphology of beetles species representing different ecological niches. Bulletin of Environmental Contamination and Toxicology, 102(2), 191-197.

Spomer, S. M., Brewer, G. J., Fritz, M. I., Harms, R. R., Klatt, K. A., Johns, A. M., Crosier, S. A., \& Palmer, J. A. (2015). Determining optimum soil type and salinity for rearing the federally endangered salt creek tiger beetle, Cicindela (Ellipsoptera) nevadica lincolniana Casey (Coleoptera: Carabidae: Cicindelinae). Journal of the Kansas Entomological Society, 88(4), $444-449$.

Sukhodolskaya, R. (2013). Intraspecific body size variation in ground beetles (Coleoptera, Carabidae) in urban - suburban - rural - natural gradient. Acta Biologica Universitatis Daugavpiliensis, 13(1), 121-128.

Sukhodolskaya, R. A., \& Eremeeva, N. I. (2013). Body size and shape variation in ground beetle Carabus aeruginosus F.-W., 1822 (Coleoptera, Carabidae) Contemporary Problems of Ecology, 6(6), 609-615.

Sukhodolskaya, R. A., \& Saveliev, A. A. (2014). Effects of ecological factors on size-related traits in the ground beetle Carabus granulates L. (Coleoptera, Carabidae). Russian Journal of Ecology, 45(5), 414420.

Sukhodolskaya, R. A., \& Saveliev, A. A. (2017). Impact of environmental factors on the body shape variation and sexual shape dimorphism in Carabus granulatus L. (Coleoptera: Carabidae). Zoological Systematics, 42(1), 71-89.

Sukhodolskaya, R., \& Ananina, T. (2017). Elevation changes of morphometric traits structure in Pterostichus montanus Motch. (Coleoptera, Carabidae). Asian Journal of Biology, 2(2), 1-9.

Sukhodolskaya, R., \& Saveliev, A. (2016). Intra-specific body size variation of ground beetles (Coleoptera: Carabidae) in latitudinal gradient. Periodicum Biologorum, 118(3), 273-280.

Szentkiralyi, F., Bernath, B., Kadar, F., \& Retezar, I. (2005). Flight of ground beetles towards polarized and unpolarized light sources. DIAS Report, 114 313-324.

Tamutis, V., Tamutel, B., \& Ferenca, R. (2011). A catalogue of Lithuanian beetles (Insecta, Coleoptera). Zookeys, 121, 1-494.

Theiss, S., \& Heimbach, U. (1994). Laborzuchtverfahren für laufkäfer der art Bembidion tetracolum (Coleoptera: Carabidae) [Laboratory method for rearing the ground beetle species Bembidion tetracolum (Coleoptera: Carabidae)]. Entomologia Generalis, 19(1-2), 61-64.

Thiele, H.-U. (1977). Carabid beetles in their environments: A study on habitat selection by adaptations in physiology and behaviour. Springer-Verlag, Berlin.

Turin, H. (2000). De Nederlandse loopkevers - verspreiding en oecologie (Coleoptera: Carabidae). Nederlandse Fauna 3. Nationaal Natuurhistorisch Museum Naturalis, KNNV Uitgeverij \& EIS Nederland, Leiden.

Tyler, G. (2010). Variability in colour, metallic lustre, and body size of Carabus arvensis Herbst, 1784 (Coleoptera: Carabidae) in relation to habitat properties. Entomologica Fennica, 21, 90-96.

Van Dijk, T. S. (1996). The influence of environmental factors and food on life cycle, ageing and survival of some carabid beetles. Acta Jutlandica, 71(2), 11-24.

Vittum, P. J., \& Morzuchi, B. J. (1990). Effect of soil pH on Japanese beetle (Coleoptera: Scarabaeidae) oviposition in potted turfgrass. Journal of Economic Entomology, 83(5), 2036-2039.

Wallin, H., Chiverton, P. A., Ekbom, B. S., \& Borg, A. (1992). Diet, fecundity and egg size in some polyphagous predatory carabid beetles. Entomologia Experimentalis et Applicata, 65, 129-140.

Weller, B., \& Ganzhorn, J. U. (2004). Carabid beetle community composition, body size and fluctuating asymmetry along an urban-rural gradient. Basic and Applied Ecology, 5(2), 193-201.

Zamotajlov, A. S., \& Nikitsky, N. B. (2010). Zhestkokrylye nasekomye (Insecta Coleoptera) Respubliki Adygeya (annotirovannyj katalog vidov) [Coleopterous insects (Insecta, Coleoptera) of Republic of Adygheya (annotated catalogue of species)]. Adyghei State University Publishers, Maykop (in Russian)

Zherebcov, A. K. (2000). Opredelitel' zhuzhelic Respubliki Tatarstan [Key to ground beetles of the Republic of Tatarstan]. Institut Ekologii i Prirodnykh Sistem AN RT, Kazan (in Russian). 